\title{
Kamusal Çocuk Oyun Alanlarında Güvenliğin Avrupa Standartları Üzerinden Değerlendirilmesi
}

\author{
Hazal Mine SARIASLAN SENYEN ${ }^{*}$, Elmas ERDOĞAN ${ }^{2}$ \\ ${ }^{1}$ Türk Standardları Enstitüsü, Belgelendirme Merkez Başkanlığı, Necatibey Caddesi No:112 06100 ANKARA \\ ${ }^{2}$ Ankara Üniversitesi, Ziraat Fakültesi, Peyzaj Mimarlığı Bölümü, 06120, ANKARA
}

Öz

Oyun, çocukların zihinlerini uyararak bilişsel, fiziksel ve sosyal olarak gelişmelerine olanak tanır. Bu araştırma, günümüzde yaygın olarak tercih edilen çocuk oyun alanlarının ve çocuk oyun donanımının güvenilirliğini ortaya koymak amacı ile gerçekleştirilmiştir. Bu makale kapsamında, Ankara'daki rekreasyon alanlarında bulunan çocuk oyun elemanları ve kurulu oldukları oyun alanlarının Türkiye'de yürürlükte bulunan TS EN 1176 seri standartlarına uygunluğunun belirlenmesi amaçlanmaktadır.

Ankara ili, Çankaya ilçesi sınırları içinde farklı semtlerde yer alan ve yapım yılı, yapım ihalesi koşulları ile alan büyüklüğü göz önünde bulundurularak belirlenen parklar içindeki çocuk oyun alanlarındaki oyun elemanları için standartlar saptanarak her oyun alanı donanımı için muayeneler yapılmışıır.

Çalışma sonucunda, belirlenen parklardaki çocuk oyun donanımının standartlarda belirtilen koşulları sağlayıp sağlamadığı irdelenmiştir. İncelenen oyun donanımında çok sayıda uygunsuzluk tespit edilmiş olup en sık rastlanan olumsuzluklar yapısal bütünlüğün korunmaması ve darbe alanlarının boyut ve özellik yönüyle yetersizliği olarak ortaya çıkmaktadır. Oyun elemanlarında bulunan uygunsuzlukların nelerden kaynaklandığ 1 tespit edilerek giderilmesine ilişkin öneriler getirilmiştir.

Anahtar Kelimeler: Çocuk oyun elemanları, kamusal alan, standartlar, güvenlik

\section{Evaluation of Safety on European Standards in Public Playgrounds}

\section{Abstract}

Play stimulates children's minds and allows them to develop cognitively, physically and socially. This study was carried out to reveal the reliability of children's playgrounds and playground equipment which are widely preferred today. In this regard, this study determines the compliance with the TS EN 1176 series Standards.

The standards have been determined for the playground equipment in the parks which are located in different neighborhoods within the boundaries of Çankaya district of Ankara province. The selection criteria for the parks are based on their construction year, construction tender conditions and area size. Each playground equipment was reviewed in its area.

As a result, the study revealed whether the playgrounds and playground equipment meet the European standard conditions. A large number inappropriate measurements or conditions in playgrounds have been determined. The most common negative outcome is that there is a lack of shock absorber surface and the lack of structural integrity. Suggestions have been made for the elimination of the inappropriate conditions found in the play elements.

Keywords: Playground equipment, public space, standards, safety. 


\section{Giriş}

Oyunun çocuk gelişimi üzerindeki olumlu etkileri uzun zamandır bilinmekte ve kuşkusuz bu konuda çalışan uzmanlarca kabul edilmektedir. Uzmanlar bu olumlu etkileri gerçek hayatın bir parçası ve çocuk için en etkin öğrenme süreci olan oyunun çok yönlü olduğunu vurgulayarak, ince ve kaba motor gelişimini, dil gelişimini, sosyalleşmeyi, kişisel farkındalığı, duygusal olarak iyi olma halini, yaratıcılı̆̆ı, problem çözme, karar verme ve öğrenme yeteneklerini etkilediğini açıklamıştır (Dönmez, 1992; Yörükoğlu, 2004; Çolak,2009). “Oyun” kelimesinde mutlak surette bir akıl ve beden becerisi vardır (Çolak, 2009). Ayrıca Yörükoğlu'na göre oyun, çocukların baş uğraşısı ve en önemli işidir; çocuğun toplumsal bir varlık olarak gelişmesinde en doğal ortam olup, kendi kişiliğini tanımasına ve kendini başkalarından ayıran özelliklerin farkına varmasına yardımcı olur (Yörükoğlu, 2004). Oyun gereçleri ise çocukların oyuna ilişkin süreçlerin ve sistemlerin nasıl çalıştığına yönelik algılarının oluşmasına yardımcı olur, hayal gücünü geliştirerek yeni fikirler üretmesinin yolunu açar, hareket kontrolü, kas kuvveti kazanmasını ve oyuna yönelik problemleri çözmede diğer çocuklarla işbirliğini öğrenmesi sağlar (URL-2, 2018).

Avrupa'da yapılan araştırmalar, iç mekânda oynanan oyunlara göre dış mekânlarda oynanan oyunların çocuk gelişimini ve yaratıcılığını daha çok desteklediğini göstermektedir (Gülay Taşçı, 2010). Geçmişte mahalle aralarında, sokaklarda oynanan oyun, bugün çocukların sportif gereksinimlerini karşılayacak, görsel nitelikleri yüksek, temel işlevlerin yanında çocukların zihninde merak, macera ve hayalperestlik kavramlarını ortaya çıkaracak tanımlı ve tasarlanmış alanlar gerektirmektedir.

Türkiye'de 1990'lı yılların ortalarından bu yana rekreasyon alanları, birden çok kullanıma hizmet edecek şekilde planlanmaya başladığı görülmektedir. Çocuk oyun alanları da, hemen her parkta yer alan kullanımların başında gelmektedir. Tek başına oynamayı tercih etmemeleri ve oyun sırasında seyirci istemeleri, çocukların kamusal alanda bulunan oyun alanlarına yönelmesine neden olmaktadır (Yılmaz ve Bulut, 2002).

Pınar Metin tarafından oyun alanı tasarımının çocukların gelişimsel gereksinimleri üzerindeki etkileri ile ilgili olarak 2003 yılında yapılan bir çalışma kapsamında geleneksel oyun alanlarının, yaratıcılık, bireysellik ve problem çözme yeteneklerine olan katkısı tartışılmaktadır. Buna göre günümüz çocuk parklarının, oyun kavramı bağlamında değerinin az olduğu, çocuğun fiziksel ve sosyal gelişimine sınırlı bir katkıda bulunduğunu ve bu tipteki oyun elemanlarının çocuğun bilişsel ve duygusal gelişimine katkıda bulunmadığı sonucuna varılmıştır (Metin, 2003). Bu bağlamda risk yeniden tanımlanmakta ve sınırları çizilmektedir. Çalışma sonucunda oyun alanının fark edilebilir riskler sunmasının yanı sıra, fiziksel aktivite açısından nitelikli olarak kabul edilebilmesi için salıncak, kaydırak gibi oyun donanımın yanı sıra tırmanma alanları, geniş katılımlı sosyal etkileşim için gösteri alanları (amfi vb.), etkinlik alanları (duvar boyama vb.), farklı dokuların algılanabilmesi açsından kum havuzu, su oyunları ve hayal gücünün desteklenmesi için üzerinde herhangi bir yapının bulunmadığı gerek bitki örtüsü gerekse topoğrafik yapısı yönüyle doğal alanlara da yer verilmesi gerektiği araştırmacı tarafından sunulmuştur. Rekreasyon alanlarındaki oyun alanları bu bakış açısıyla ele alındığında bu unsurlar bulunmadığı gibi tip, model ve malzeme olarak birbirine benzer oyun elemanlarına yer verildiği görülmektedir.

Son yıllarda, ürünlerini Avrupa Standartlarına göre belgelendiren kuruluşlarla yapılan görüşmelerde küresel ticaret ve teknolojik gelişmelerin yeni tasarımları herkes tarafından görülebilir hale getirdiği anlaşılmaktadır. Türkiye'de bu alanda faaliyet gösteren kurumsal şirketlerin gerek küresel ölçekte gerek ülke ölçeğinde rekabet edebilmesi için standartlara uygun üretim yapma konusundaki farkındalığı artmış ve bu doğrultuda oyun alanları bir değişime uğramıştır. Ancak bu değişimin oyun alanlarının birbirinden farklılaşması yönünde bir etki yaptı̆̆ı söylenemez.

Oyun alanı elemanları konusunda hazırlanan standartlara bakılacak olursa oyun donanımının niteliği ne olursa olsun, bir oyun alanı tasarlarken, kurarken ve işletirken ele alınması gereken en önemli unsurun güvenlik olduğu görülmektedir. Zira TS EN 1176-1 tek başına bir güvenlik standardıdır. Güvenli oyun olanaklarının olmadığı, yaralanmalara sebebiyet verebilecek tehlikeli durumların ortaya çıkma riskinin yüksek olduğu bir ortamda, şüphesizdir ki çocuğun gelişiminden söz etmek mümkün değildir.

Oyun alanlarında, gözetim eksikliğine ve birçoğu da oyun elemanları ve tasarıma bağlı çok sayıda tehlike ve risk bulunmaktadır. Amerika Birleşik Devletleri Tüketici Ürün Güvenliği Kurumu (U.S. Consumer Product Safety Commission)'nun raporlarına göre her yıl 200.000'den fazla çocuk oyun alanı elemanlarından kaynaklanan yaralanmalar nedeniyle acil servise başvurmaktadır. Bu yaralanmaların \%70'i kamusal alanda bulunan oyun donanımından kaynaklanmaktadır (Chait, 2016). Kamusal oyun alanı, gündüz bakım evleri, okullar, site yerleşimi benzeri toplu konut alanları, park alanları, açık yeşil alanlar, restoranlar, rekreasyon 
amacıyla kurulan panayır vb. kamusal alanlarda kurulu, 6 ay-12 yaş arası çocukların kullanımı için tasarlanmış oyun donanımı olarak tanımlanabilmektedir (URL-1, 2015). Oyun alanında yaşanan tüm yaralanmaların \%70'i düşerek zemine çarpamaya bağlıdır ve 0-4 yaş arasındaki çocukların $\% 60$ 'ı kafa ve yüz yaralanmalarıyla karşılaşmaktadır. (Chait, 2016).

İngiltere'deki oyun alanlarında yaşanan kazaların incelendiği rapora göre her yıl 40.000 çocuk hastaneye başvurmakta ve bu yaralanmaların \%80'i düşmeye bağlı olarak gerçekleştiği belirtilmektedir (URL-3, 2018). Aynı rapora göre çocukların en fazla salıncaktan düşmekte ve yaralanmaların \%20'si salıncak çarpması, el ve ayak sıkışması gibi nedenlerle ortaya çıkmaktadır.

2005 yllında İsrail'de tıbbi müdahale gerektiren düşmelerin \%4'ü oyun alanlarından kaynaklanmıştır (Sethi et. al, 2008).

Avrupa Birliği ülkeleri genelinde her yıl ortalama 5.600 çocuk oyun alanlarında meydana gelen düşme olaylarından dolayı tıbbi hizmet almaktadır. Düşmelere bağlı yaralanmalar, oyun alanlarında gerçekleşen yaralanmaların \%72'sini oluşturmaktadır (Sethi et. al, 2008).

Çocuklar büyüdükçe, oyun alanı donanımındaki fiziksel aktiviteye bağlı olarak düşme sıklığı da artmakta ve bu düşüşler genellikle yatarak tedavi gerektiren kafa yaralanması ile sonuçlanmaktadır (Sethi et. al, 2008). Oyun alanlarının güvenliği ile ilgili çalışmalar, oyun alanı elemanlarının yükseklik ve daha az emici temas yüzeyleri gibi yapısal özellikleri ile düşmeye bağlı yaralanmalar arasında önemli ilişkiler olduğunu göstermektedir. Araștırmalar, yeterli derinlikteki uygun yüzey malzemelerine ve uygun korkuluklara sahip olmak gibi, kabul edilen güvenlik standartlarına uymayan oyun parklarında düşerek yaralanma riskinin arttığını ortaya koymaktadır.

İsveç'te, oyun alanlarında her yıl yaklaşık 12.000 yaralanma olmaktadır ki bu çocuk yaralanmalarının \% 6'sına denk gelmektedir (Sethi et. al, 2008). 1995-1996 yılları arasında kaydedilmiş oyun alanında yaralanma olaylarının yaklaşık \% 55'i kırık, çıkık ve beyin sarsıntısı ile sonuçlanmıştır.

Kore'de oyun alanlarında yaşanan kazalar sonucu beyin travması ve uzuvlarda kırık riskini ortaya koymak amacıyla 2011-2014 yılları arasında yapılan bir araştırmaya göre, hastaneye başvuran 0-7 yaş aralığındaki 6.110 çocuğun \%48,5'i düşmelere bağlı olarak yaralanmıştır (Bae et. al, 2017). Kaydıraklara bağlı yaralanmaların oranı \%40,5, salıncaklara bağlı yaralanmaların oranı \%18'dir ve yaralanmaların \%56,6'sı baş ve boyun yaralanmalarıdır. Beyin sarsıntısı 0-2 yaş aralığındaki çocuklarla ve salıncaklarla ilişkilendirilirken, el ve kol kırılmaları 3-7 yaş aralığındaki çocuklar ve tırmanma elemanları ile ilişkilendirilmiştir. Ayak, bacak kırılmalarına sebep olan oyun elemanları yatay bar, gerili ip ve trambolinler olarak belirtilmiştir.

Türkiye'de oyun alanlarında gerçekleşen kazalar ve sonuçları ile ilgili herhangi bir istatistik veri bulunmamaktadır (TÜİK, 2018). İçişleri Bakanlığı Mahalli İdareler Genel Müdürlüğü tarafından 81 il valiliğine gönderilmiş olan 28.02.2018 tarih ve E.4904 sayılı yazıya istinaden, kamu alımı yoluyla temin edilmiş olan oyun alanları ve oyun elemanları ilk kurulum sürecinde Avrupa standartlarına uygunluğu yönünden değerlendirilmektedir. Bunun yanında oyun alanı elemanlarının Türkiye 'de uygulamada bulunmayan standartlar yönüyle değerlendirildiği çalışmalar da bulunmaktadır. 2008 yılında Isparta'da 57 kamusal oyun alanında Amerika Birleşik Devletleri'ndeki düzenlemeler dikkate alınarak yapılan değerlendirme sonucunda, incelenen oyun alanlarının $\% 80,7$ 'sinin zemin düzenlemesinin yetersiz olduğu, $\% 52$ 'sinde uygun olmayan donanım bulunduğu tespit edilmiştir (Uskun et. al, 2008). Aynı güvenlik ölçütleri doğrultusunda Elazığ'da kent merkezinde bulunan 24 oyun alanında yapılan bir araştırmaya göre, oyun alanlarının \%87,5'i uygun zemin yüzeyi özelliklerine sahip olmamakla birlikte incelenen oyun alanlarının $\% 95,8$ 'inde güvenli olmayan oyun donanımı, \%83,3'ünde ise keskin kenar, sivri uçlar ve yaralanmalara sebebiyet verecek birikintiler olduğu tespit edilmiştir (Açık et. al, 2004).

Oyun alanının işlerliği, sürdürülebilirliği ve tercih edilmesi, tasarımından ebeveynlerin beklentilerine kadar çeşitli konulara bağlıdır. Oyun ortamının davet edici özelliklerinin ve keşfetmeye olanak tanımasının ötesinde şüphesiz en önemli konu güvenli olmasıdır. Ancak güvenli oyun alanından, hiçbir risk içermeyen oyun donanımı anlaşılmamalıdır (TS EN 1176-1, 2010). Oyun oynamak deneyerek sınırların ötesine geçmek olduğundan, ideal oyun alanı tehlikeli olmadığı sürece görünür ve yönetilebilir riskler sunmalıdır (Jakat, 2018).Çocuklar, problem çözme yeteneklerini artıran bu eylemler sırasında risklerin farkına varmakta ve bu risklerin algılanma şekline göre karar verme yeteneklerini de geliştirebilmektedirler. Oyun alanı ile ilgili standartların temel amacı, çocukların yaralanma riskinin en aza indirilmesi için önem taşıyan hususların kontrol edilerek güvenliğin garanti edilmesi olarak açıklanabilmektedir. Oyun alanı donanımı ve zemin düzenlemeleri 
için hazırlanmış ve Türk Standardı olarak kabul edilmiş olan Avrupa standartları yetişkinler için erişilebilirlik, yakalanma ve düşmeye karşı koruma, zemin düzenlemeleri, darbe alanları ve bakım konularını ele almakta ve sakatlanmalara ya da ölümcül sonuçlara sebep olabilecek kazaları önlemek amacıyla alınması gereken önlemlerden bahsetmektedir (TS EN 1176-1, 2010).

Oyun alanlarında çocuk güvenliğinin sağlanması, kullanıcılar için anlaşılabilir/öngörülebilir olmayan tehlikeleri ortadan kaldırarak risklerin en alt düzeye indirilmesi anlamını taşımaktadır. Genel güvenlik standardı TS EN 1176-1'e göre çocukların öngöremeyeceği tehlikeleri yaratan hususlardan bazıları; uygun olmayan koruyucu yüzey, oyun elemanlarının güvenlik alanlarının yetersiz olması, keskin çıkıntı ve kenarlar, kafa ve diğer uzuvların yakalanması, oyun alanının kalabalık olması, oyun zemininde takılmaya sebep olabilecek beklenmedik engeller, yetişkin gözetimi eksikliği, bakım eksikliği olarak sıralanabilmektedir (TS EN 1176-1, 2010).

TS EN 1176-1'e göre tehlikelerin ortadan kaldırılarak risklerin en aza indirilmesi için önem taşıyan hususlar gene olarak aşağıdaki gibidir;

- Düşme alanının darbe emici özelliklere sahip olması,

- Oyun donanımının tasarımının standartlarda belirtilen boyut, ölçü ve özellikler göz önüne alınarak yapılması ve tasarlandığı şekliyle alana uygulanması,

- Oyun sırasında yetişkin erişimine olanak sağlanması,

- Oyun donanımı ve zemin kaplamalarının insan sağlığı için zararlı olabilecek tehlikeli maddeler içermemesi ve alevlenme riski taşımaması,

- Oyun alanı içindeki elemanların birbirleriyle olan ilişkileri ile oyun alanının dış çevre ile olan ilişkilerinin darbe alanları ve erişilebilirlik yönüyle uygun olması,

- Oyun alanının ve oyun donanımının yapısal bütünlüğünün standartta belirtilen sıklıkta (gözle rutin muayene, işletme muayenesi (1-3 ay), yıllık muayene) kontrolü ve devamlılığının bakım ile sağlanmasi.

Standardın herhangi bir maddesine uymayan oyun donanımı veya zemin düzenlemesi olumsuz olarak kabul edilmektedir. $\mathrm{Bu}$ nedenle, oyun alanı elemanları ve zemin düzenlemeleri standartlarının maddeleri arasında önemli/ daha önemli gibi bir sınıflama yapmak doğru olmaz. Oyun donanımının tüm aralıkları, boyutları, yükseklikleri ve taşıyıcı özellikleri standartlarda belirtilenlerden sapma göstermeyecek şekilde planlanmalı ve uygulanmalıdır.

Gerek Türkiye'de gerek dünya genelinde, oyun alanlarında en çok karşılaşılan kazalar düşmeye bağlı olarak gerçekleşmektedir ve yapılan çalışmalar çoğunlukla düşmeye bağlı olarak ortaya çıkabilecek yaralanmaların azaltılmasına yöneliktir. Bu bakış açısıyla ele alındığında, oyun donanımının yüksekliğini sınırlamak ve farklı yükseklikteki elemanlar için korkuluk, bariyer gibi gerekli kenar koruma unsurlarını sağlamak, darbe emici zemin düzenlemelerinde donanımın yüksekliğini dikkate almak, darbe alanları ve düşme boşluğunu engellerden arındırmak gibi -aslında standardın birer gereği olan- önlemler ile beklenmedik, öngörülemeyen düşmelerin önüne geçilebilmektedir.

Oyun alanını çevreleyen bitkisel veya yapısal elemanlar, oyun donanımının darbe alanlarını (kullanıcının oyun donanımından düştükten sonra çarpabileceği alan) işgal etmemeli, yaralanmalara sebebiyet vermeyecek şekilde tasarlanmalı, görüşü ve erişimi engellememelidir. Örneğin sınır elemanı olarak canlı materyal kullanıldığı durumlarda dikenli bitki kullanımından kaçınılmalıdır. Kalıcı olarak kurulmuş dış mekân egzersiz donanımları çocuk oyun alanlarının hemen yakınına kurulum için tasarlanmamıştır. Egzersiz donanımı, oyun alanı donanımı ile bağlantılı olarak, oyun alanları veya benzeri yerler üzerine kurulmuş ise, bu donanım uygun mesafe, çit veya diğer yapısal önlemler ile genel oyun aktivitelerinden ayrılmalıdır (Cronan, 2018; TS EN 1176-1, 2010; TS EN $16630,2015)$.

Yukarıda da bahsedildiği gibi, istatistikler ve yapılan araştırmalar, yoğun olarak düşme ve buna bağlı oluşan durumlara odaklanmış olsa da oyun alanlarında sıklıkla karşılaşılabilecek bir diğer olumsuz durum da yakalanmalardır. Her oyun donanımının kendine has nitelikleri olduğu gibi, tasarımına bağlı olarak sıkışma ve yakalanmaya sebep olabilecek çeşitli açıklıkları ve kısımları bulunmaktadır. Standartta belirtildiği şekilde tasarlanmayan ve uygulanmayan oyun donanımından kaynaklanabilecek yakalanmalar, çıkık, kırık, boğulma veya uzuv kaybı ile sonuçlanabilmektedir. Oyun elemanlarının yüzeyi herhangi bir yaralanmaya sebebiyet vermeyecek şekilde işleme tabi tutulmalı, hareketli parçalar arasında ezici veya kesici uçlar bulunmamalı, oyun elemanlarında yer alan açıklıklar ve aralıklar, parmak, ayak, bacak, tüm vücut, giysi, saç, baş ve boyun yakalanmalarına sebebiyet vermeyecek ölçülere tasarlanmalı ve uygulanmalıdır (TS EN 1176-1, 2010). 
Durani'ye göre, oyun alanları tasarlanırken 2 yaş altı, 2-5 yaş arası ve 5-12 yaş arası olmak üzere üç farklı yaş grubu dikkate alınmalıdır (Cronan, 2018). Yaş aralıklarına göre zorluk seviyelerinin değişmesine gereksinim olsa da standarda göre riske karşı koyma yeteneği yaşa değil fiziksel güce bağlıdır ve o zorluk derecesine uygun olmayan yaş grubunun oyun donanımına erişimi önlenemez (TS EN 1176-1, 2010). Bu nedenle standartta herhangi bir yaş aralığı için tanımlı oyun donanımı veya koşullar bulunmamakla birlikte üreticiler donanımın hitap ettiği yaş aralığını ve amaçlanan kullanıcı grubuna uygun zorluk derecesini belirtmekle yükümlüdürler. $\mathrm{Bu}$ noktada yetişkin gözetimi ve oyun donanımına erişiminin önemi ortaya çıkmaktadır. Oyun alanı ve oyun donanımı, yetişkinlerin herhangi bir anda çocuğa erişebilmesine olanak sağlayacak şekilde tasarlanmalıdır (TS EN 1176-1, 2010). Oyun donanımının geçiş tünelleri gibi kapalı bölümleri görüşü tamamen engelleyecek düzeyde kapalı olmamalıdır.

Çevresel faktörler, kullanım ve estetik kaygı oyun alanı donanımının yapımında kullanılan malzemeler seçilirken göz önünde bulundurulmalıdır (Cain Ruth, 2018). Ancak, Avrupa standartlarına göre oyun alanı ve donanımının güvenliği söz konusu olduğunda bu unsurların önüne geçen hususular ortaya çıkmaktadır. Malzeme seçimleri, dayanıklı malzemeler arasından yapılmalı ve malzemeler asbest, formaldehit gibi insan sağlığını olumsuz olarak etkileyecek tehlikeli kimyasallar içermemelidir. Oyun alanında kullanılan hiçbir malzeme ani yüzey parlaması yapmamalıdır. Oyun donanımı amaçlanan kullanıcı sayısı çerçevesinde belirlenen yükler altında kararlı olmalıdır (TS EN 1176-1, 2010). Genel güvenlik standardına göre Yapısal bütünlüğün devamlılığının sağlanabilmesi amacıyla, metal malzemeler korozyona karşı korunmalı, ahşap malzemeler ahşap koruyucular ile işleme tabi tutulmalıdır (TS EN 1176-1, 2010).

Salıncaklarda, tekli bağımsız oturma bölümleri içeren atlıkarıncalarda veya oturma tipi kablolu taşıma düzeneklerine kullanılan oturaklar, uygun deney düzeneğinde deneye tabii tutulduğunda ivme değerleri ve yüzey sıkışması standardın ilgili maddesine uygun olmalı, asılma sistemindeki bileşenlerde kalıcı hasar ve şekil bozuklukları meydana gelmemelidir (TS EN 1176-2, 2010). Bu anlamda, deney yeterliliği olan akredite laboratuvar yetkilileriyle yapılan görüşmede, salt polietilen malzeme kullanılarak yapılan salıncak oturaklarının tamamının deneylerden olumsuz sonuç aldığ Atlıkarıncaların dönme hızı ile kablolu taşıma tesisatlarının hızı standartlarda verilen değerleri aşmamalıdır (TS EN 1176-5, 2010; TS EN 1176-4, 2010).

Her bir kaydırak tipi, standartta verilen doğrusal ve açısal ölçüler ile serbest boşluk ölçülerini karşılamalı, çocuğun başlama bölümünden düşmesini engelleyecek yöntemler uygulanmalıdır. Kaydıraklar ile ilgili risklerden biri de giysi veya saç yakalanmasıdır (TS EN 1176-1, 2010). Kaydırakların ve bağlı oldukları yapıların hiçbir parçası giyecek veya saç yakalanmasına olanak vermeyecek şekilde olmalıdır (TS EN 1176-3, 2010). Serbest düşme yüksekliğine göre belirlenen darbe alanlarına ek olarak kaydırak çıkış tipine göre ilave darbe alanları standarda uygun olarak hesaplanmalı ve donanımın kurulacağı alan bu ölçüler 1şı̆̆ında belirlenmelidir (TS EN 1176-1, 2010).

TS EN 1176-6'da verilen koşullara göre tahterevallinin eksen eğimi ve eksenin ana hattan sapması, darbe sönümleme özellikleri ile tek noktaya bağlı sallanma elemanlarının yayda yaptığı sıkışma, tip özelinde genel güvenlik kuralları haricinde dikkat edilmesi gereken hususların başında gelmektedir. Elemanın ana gövde formundan çıkıntı yapan parçalar yaralanmalara sebebiyet vermeyecek şekilde yuvarlatılmış olmalıdır (TS EN 1176-6, 2010).

Standarda göre üreticilerin, oyun alanına ilişkin güvenli kurulum (asgari boşluklar, zemin özellikleri, hedef alınan yaş grubu), işletme, kontrol sıklığı ve bakım ile ilgili bilgileri müşteriye sunması gerekmektedir. Oyun alanı elemanı, üretici iletişim bilgileri, elemanın üretim yılı ve uygun olduğu standardın numarası ile temel seviye gösterimi yer alacak şekilde okunaklı ve kalıcı bir şekilde işaretlenmelidir (TS EN 1176-1, 2010). Oyun alanının sürdürülebilirliğinden sorumlu kurum tarafından, oyun alanı belirli aralıklarla kontrol edilmeli, yabancı maddeler varsa uzaklaştırılmalı ve oyun donanımının niteliğini kaybetmiş ve yapısal bütünlüğün bozulmasına sebep olabilecek kısımlarının değiştirilmesi için gerekli girişimlerde bulunulmalıdır.

\section{Materyal ve Metot}

$\mathrm{Bu}$ çalışmanın oyun alanlarının standartlara uygunluğunun belirlenmesi amacı doğrultusunda alanlar belirlenirken;

- Büyüklüğün, yoğunlukla ilişkili olmasına bağlı olarak toplam alanın 5000m2'den büyük olması,

- Yürürlükte bulunan oyun alanı elemanları ve zemin düzenlemeleri standartlarının yürürlük tarihi olan 2010 yılından sonra yapılmış olması, 
- Belgelendirmeye esas standartların zorunlu standart olmaması nedeniyle, yapım ihalesi teknik şartnamesinde ilgili standartlara göre düzenlenmiş olan uygunluk belgelerinin talep edilmiş olması seçim ölçütleri olarak kabul edilmiştir.

Araştırma materyali olarak belirlenen ölçütler doğrultusunda belirlenen parklardaki oyun alanlarında bulunan çocuk oyun elemanları saptanmış ve ilgili ürün standartları belirlenmiştir.

\subsection{Materyal}

İnebolu Parkı, Füsun Sayek Parkı ve Öysekent Doğa Parkı çalışma alanı olarak belirlenmiştir.

- İnebolu Parkı

Ankara İli, Çankaya İlçesi, Keklik Pınarı Mahallesi’nde 901. cadde ile 918. sokağın birleştiği noktada bulunan ve yüzölçümü yaklaşık $5050 \mathrm{~m}^{2}$ olan İnebolu Parkı (Şekil 1) içindeki $170 \mathrm{~m}^{2}$ alana kurulu olan oyun alanında; 1 adet tek döner eksenli salıncak, 1 adet B tipi atlıkarınca, iki adet eksenel (düşey hareketli) tahterevalli ile kaydırak grubu elemana bağlı 1 adet bağlı kaydırak, 1 adet tünel kaydırak, 1 adet çoklu bağlı kaydırak ve 1 adet spiral kaydırak olmak üzere toplam dört tip kaydırak bulunmaktadır.

- Füsun Sayek Parkı

Ankara İli, Çankaya İlçesi, Çukurambar Mahallesi'nde 1427. Cadde, 1505. Cadde ve 1507/2 sokak arasında konumlandırılmış (Şekil 1) Füsun Sayek Parkı'nın toplam alanı yaklaşık $6650 \mathrm{~m}^{2}$ 'dir. Park toplam alan içinde de büyüklüğ̈ $45 \mathrm{~m}^{2}$ olan oyun alanı bulunmaktadır. Oyun alanı içinde kaydırak dışında herhangi bir oyun elemanı bulunmamaktadır.

- Öysekent Doğa Parkı

Ankara İli, Çankaya İlçesi, Ahlatlıbel Mahallesi'nde 1859. Cadde ile 1835. Cadde kesişim noktasında bulunan (Şekil 1) Öysekent Doğa Parkı'nın yüzölçümü yaklaşık $13350 \mathrm{~m}^{2}$ dir. Büyüklüğü $80 \mathrm{~m}^{2}$ olan oyun alanında 2 adet kaydırak elemanı, bu elemanlara bağlı 2 adet salıncak, 1 adet atlıkarınca, 1 adet tahterevalli ve 1 adet sallanma elemanı (zıp zıp) bulunmaktadır.

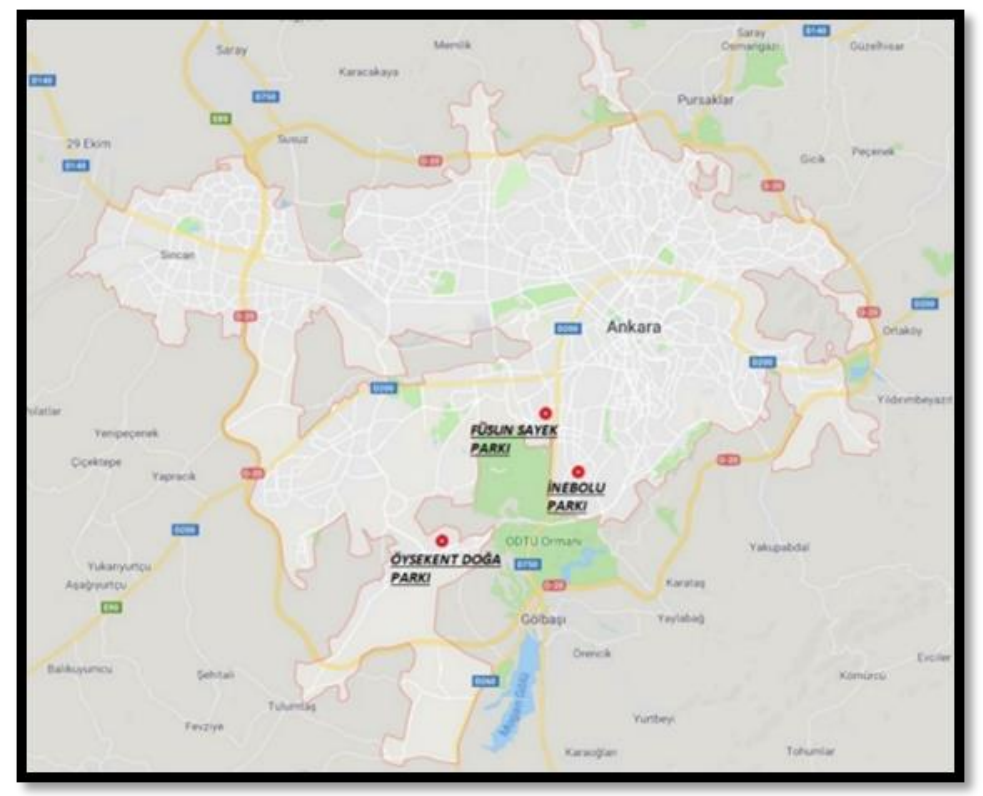

Şekil 1. Çalışma alanı olarak belirlenen parkların konumları

\subsection{Metot}

Belirlenen parklarda bulunan oyun donanımının kapsamına girdiği standartlar şu şekilde listelenebilmektedir;

- TS EN 1176-1 Oyun alanı elemanları ve zemin düzenlemeleri - Bölüm 1: Genel güvenlik kuralları ve deney yöntemleri,

- TS EN 1176-2 Oyun alanı elemanları ve zemin düzenlemeleri - Bölüm 2: Salıncaklar için ilâve özel güvenlik kuralları ve deney yöntemleri, 
- TS EN 1176-3 Oyun alanı elemanları ve zemin düzenlemeleri - Bölüm 3: Kaydıraklar için ilâve özel güvenlik kuralları ve deney yöntemleri,

- TS EN 1176-5 Oyun alanı elemanları ve zemin düzenlemeleri - Bölüm 5: Atlıkarıncalar için ilave özel güvenlik kuralları ve deney yöntemleri,

- TS EN 1176-6 Oyun alanı elemanları ve zemin düzenlemeleri - Bölüm 6: Sallanma elemanları için ilâve özel güvenlik kuralları ve deney yöntemleri

Laboratuvar şartlarında belirli test donanımı ile yapılabilen deneyler çalışma metodunun sınırlayıcısı olarak ortaya çıkmaktadır. Oyun donanımı ve elemanları bu standartlara göre, kurulu oldukları alanda gerçekleştirilebilecek muayenelere tabi tutulmuştur ancak boya, emprenye, kauçuk gibi malzemelerde tehlikeli madde analizi, salıncak oturaklarının darbe ve salınım deneyleri ile zemin kaplamasının darbe emici özelliklerinin belirlenmesine ilişkin deneyler yapılamamıştır.

Standartlarda tanımlanan ve yerinde yapılabilen muayene ve deneyler, deneye tabi tutulmasına karar verilen oyun alanı donanımı üzerinde deney cihazları (Şekil 2) ile standartlarda ölçü ve şekilleri tarif edilen ve deney mastarları denen deney aparatları (Şekil 3) kullanılarak gerçekleştirilmiştir. Kullanılan deney cihazları akredite ya da izlenebilirliği sağlanmış laboratuvarlarca düzenlenmiş kalibrasyon sertifikalarına sahip dijital eğimölçer, kumpas, şerit metre, süreölçer ve el kantarının yanı sıra, kü̧̈ük kafa ve büyük kafa mastarları, parmak mastarlar, $\mathrm{V}$ açıklık mastarı, giysi yakalama mastarı ve göz yakalama mastarları ile kaydırak çıkışları için yarıçap mastarı, çocuk oyun elemanlarının standartlara uygun olup olmadığını saptamak amacıyla kullanılmışır.

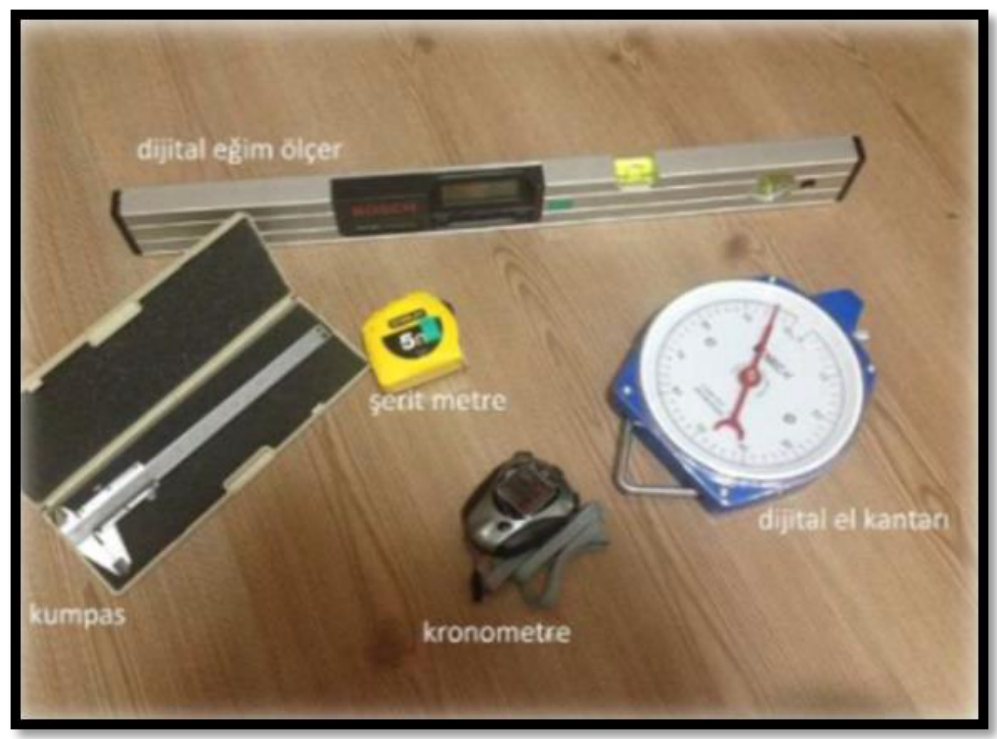

Şekil 2. Ölçüm cihazları

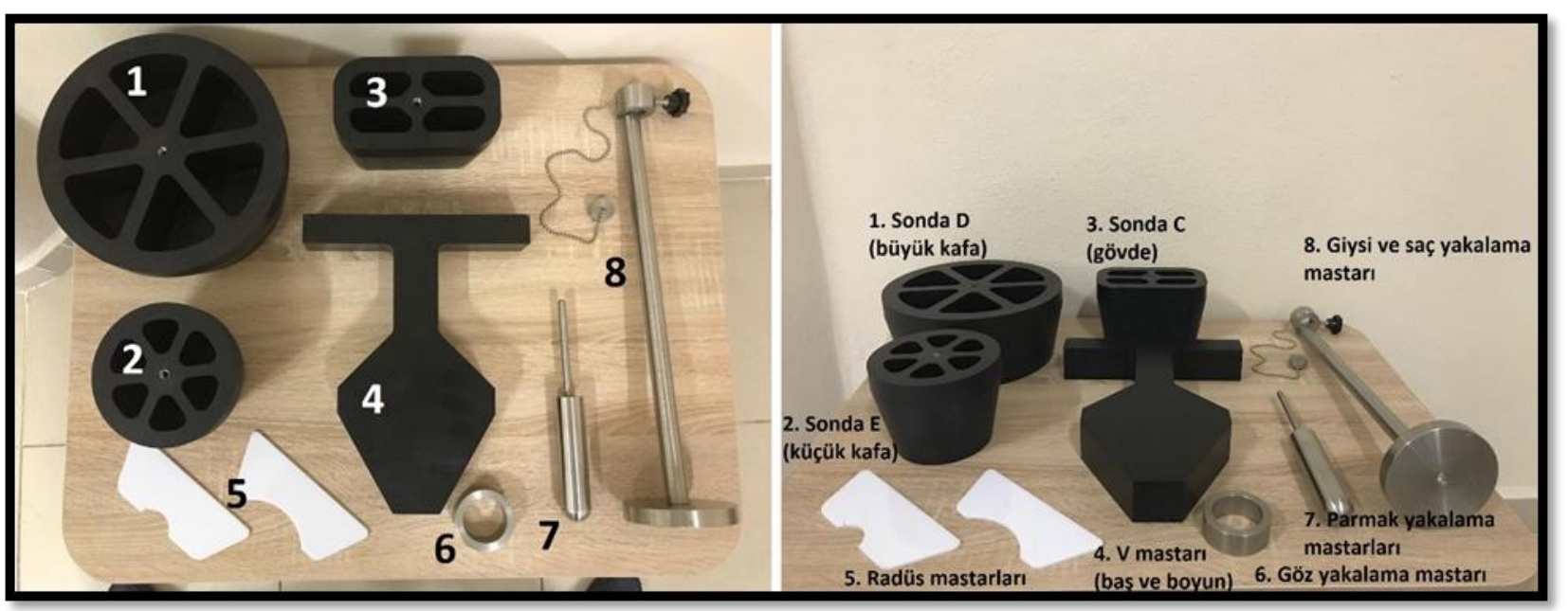

Şekil 3. Deney Mastarları 


\section{Bulgular ve Tartışma}

Belirlenen parklarda yer alan her bir oyun donanımı için yapılabilecek tüm muayeneler yapılmış, standarda uyan ve uymayan yönler saptanarak ortaya konmuştur.

\subsection{Inebolu Parkı}

İnebolu Parkı'nda bulunan oyun alanında, taşıyıcı sistem ahşap malzemeden üretilmiştir. Salıncak oturakları, atlıkarınca oturakları ve kaydıraklar polietilen malzemeden üretilmiştir.

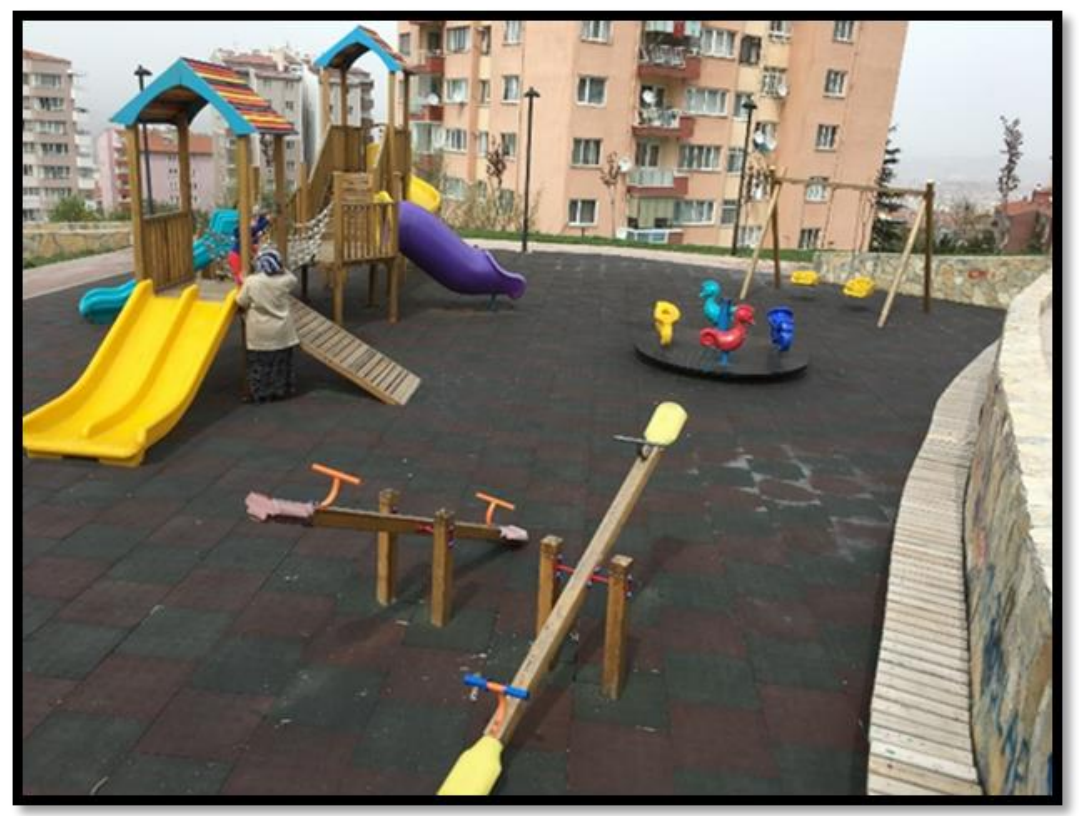

Şekil 4. İnebolu Parkı oyun alanı

Salıncağın serbest düşme yüksekliği ve zincir boyutunun standarda uyduğu tespit edilmiştir. Standartta verilen formüllere göre yapılan hesaplamalar ve ölçümler sonucunda, salıncak taşıyıcı aksamı ile oturakların birbirine göre mesafeleri, yerden yükseklik ve darbe alanı boyutlarının uygun olmadığı görülmüş ve ayrıca yaralanma riski yaratan keskin çıkıntılar ve açıklılar olduğu tespit edilmiştir (Tablo 1).

Tablo 1. Standart değerler ve İnebolu Parkı salıncak ölçüleri

\begin{tabular}{lll}
\hline Ölçüm yeri & $\begin{array}{l}\text { Hesaplanan } \\
\text { (olması gereken) }\end{array}$ & Ölçülen \\
\hline $\begin{array}{l}\text { Salıncak oturağı ile bitişik yapı arasındaki mesafe } \\
\text { İki salıncak oturağı arasındaki mesafe }\end{array}$ & $\geq 735 \mathrm{~mm}$ & 500 \\
$\begin{array}{l}\text { Zincirin taşıyıcı eksene bağlantı noktaları arasındaki } \\
\text { mesafe }\end{array}$ & $\geq 558,75 \mathrm{~mm}$ & 520 \\
Yerden yükseklik & $\geq 350 \mathrm{~mm}$ & $320 \mathrm{~mm}$ \\
Serbest düşme yüksekliği & $\leq 1500 \mathrm{~mm}$ & $1457,5 \mathrm{~mm}$ \\
Zincir özellikleri / kavrama & $6 \mathrm{~mm} \mathrm{kalibre} \mathrm{zincir} \mathrm{/}$ & $6 \mathrm{~mm} \mathrm{kalibre} \mathrm{zincir} \mathrm{/21}$ \\
Darbe alanı & $16 \mathrm{~mm}-45 \mathrm{~mm}$ & $\mathrm{~mm}$ \\
\hline
\end{tabular}

Kaydırak elemanı üzerinde yapılan inceleme ve ölçümler sonucunda rampa eğiminin, rampa yatay eğiminin, 
rampa döşeme aralıklarının uygun olduğu görülmüştür. Rampa üzerinde bulunan tutma çubuğunun kalınlığının standartta belirtilen aralıkta olduğu ancak yüksekliğinin uygun olmadığı saptanmıştır. Basamakların uygun sayıda ve eğimde olduğu, basamaklar üzerine tesis edilen tırabzanların kalınlık yönüyle olumlu yükseklik yönüyle olumsuz olduğu tespit edilmiştir. Ayrıca ip köprü kalınlığı da kavrama kurallarına uymamaktadır (Tablo 2).

Tablo 2. Standart değerler ve İnebolu Parkı kaydırak donanımı genel ölçüler

\begin{tabular}{lll}
\hline Ölçüm yeri & Olması gereken & Ölçülen \\
\hline Rampa eğimi & $<38^{\circ}$ & $29,7^{\circ}$ \\
Rampa tutma çubuğu yüksekliği & $600 \mathrm{~mm}-850 \mathrm{~mm}$ & $865 \mathrm{~mm}$ \\
Rampa tutma çubuğu kalınlığı & $16 \mathrm{~mm}-45 \mathrm{~mm}$ & $25 \mathrm{~mm}$ \\
Rampa yatay eğimi & $\leq 3^{\circ}$ & $<3^{\circ}$ \\
Rampa lata aralıkları & $\leq 30 \mathrm{~mm}$ & $10 \mathrm{~mm}$ \\
Basamak sayısı & $\geq 3$ & 5 \\
Basamak yatay eğimi & $\leq 3^{\circ}$ & $1,2^{\circ}$ \\
Tırabzan yüksekliği & $600 \mathrm{~mm}-850 \mathrm{~mm}$ & $880 \mathrm{~mm}$ \\
Tırabzan kavrama kalınlığı & $16 \mathrm{~mm}-45 \mathrm{~mm}$ & $43 \mathrm{~mm}$ ve $44 \mathrm{~mm}$ \\
İp köprü kavrama kalınlığı & $25 \mathrm{~mm}-45 \mathrm{~mm}$ & $21 \mathrm{~mm}$ \\
Korkuluk yüksekliği & $600 \mathrm{~mm}-850 \mathrm{~mm}$ & $790 \mathrm{~mm}$ \\
Korkuluk kavrama kalınlığı & $16 \mathrm{~mm}-45 \mathrm{~mm}$ & $43 \mathrm{~mm}$ ve $44 \mathrm{~mm}$ \\
Tutma noktaları kalınlığı & $\leq 60 \mathrm{~mm}$ & $45 \mathrm{~mm}$ ve $59 \mathrm{~mm}$ \\
Çatı yüksekliği & $\geq 1800 \mathrm{~mm}$ & $1650 \mathrm{~mm}$ \\
\hline
\end{tabular}

Kaydırakların platform, erişim araçları gibi parçaları genel güvenlik standardı kapsamında ele alınırken, kaydıraklar ilgili ürün standardına göre değerlendirilmektedir. Bu çerçevede TS EN 1176-3 standardına göre yapılan ölçümler Tablo 3’te verilmiştir.

Bağlı kaydırağın, tutma çubuğu yüksekliği ve kalınlığının, başlama bölümü uzunluğu ve yan koruma yüksekliği, kayma bölümü derinliği, genişliği ve ortalama eğimi ile çıkış bölümü uzunluğu, eğimi ve yüksekliğinin standarda uygun olduğu saptanmıştır. Ancak başlama bölümü eğimi standartta verilen sınırın üstünde ve olumsuzdur.

Çoklu bağlı kaydırakta platform başlama bölümü olarak kullanıldığından başlama bölümü ile ilgili kurallar değerlendirilmemiştir, tutma çubuğu kalınlığının uygun ancak yüksekliğinin uygun olmadığı görülmüştür. Çoklu bağlı kaydırağın kayma bölümü derinliği, genişliği ve ortalama eğimi, orta ayracının yüksekliği, çıkış bölümü uzunluğu ve yüksekliği yönleriyle olumlu olduğu ancak çıkış bölümünde bulunan ters eğim yönüyle olumsuz olduğu tespit edilmiştir.

Tünel kaydırağın iç çapının, kayma bölümü ortalama eğiminin standardın öngördüğü koşullara uygun olduğu görülmüştür. Çıkış bölümü uzunluğu ve yüksekliğinin uygun, çıkış bölümündeki ters eğimin uygun olmadığı tespit edilmiştir.

Spiral kaydırakta bulunan tutma çubuğu yüksekliği ve kalınlığı standartta verilen aralıklara uymaktadır. Başlama bölümü uzunluğu, eğimi ve yan koruma yüksekliği, kayma bölümü derinliği, genişliği ve ortalama eğimi ile çıkış bölümü uzunluğu, eğimi ve yüksekliğinin standarda uygun olduğu görülmüştür.

Atlıkarınca genel olarak incelendiğinde; serbest düşme yüksekliği, eksen eğimi, hız, el destekleri kalınlığı ve el çarkı tasarımı yönüyle uygun bulunmuştur. Ancak darbe alanı, el desteklerinin ve platform alt yüzeyinin yakalanmalara sebebiyet verecek şekilde tasarlanmış olması, kullanıcı yerlerinin platform dışına taşması ve polietilen aksamın çıkıntılı kısımlarının uygun yarıçapla yuvarlatılmaması uygun olumsuz olarak değerlendirilmiştir (Tablo 4). 
Tablo 3. Standart değerler ve İnebolu Parkı kaydırak ölçüleri

\begin{tabular}{|c|c|c|c|c|c|}
\hline Ölçüm yeri & Olması gereken & $\begin{array}{l}\text { Ölçülen } \\
\text { Bağlı } \\
\text { Kaydırak }\end{array}$ & $\begin{array}{l}\text { Ölçülen } \\
\text { Çoklu Bağlı } \\
\text { Kaydırak }\end{array}$ & $\begin{array}{l}\text { Ölçülen } \\
\text { Tünel } \\
\text { Kaydırak }\end{array}$ & $\begin{array}{l}\text { Ölçülen } \\
\text { Spiral } \\
\text { Kaydırak }\end{array}$ \\
\hline Tutma çubuğu yüksekliği & $600 \mathrm{~mm}-900 \mathrm{~mm}$ & $830 \mathrm{~mm}$ & $930 \mathrm{~mm}$ & - & $840 \mathrm{~mm}$ \\
\hline Tutma çubuğu kavrama & $16 \mathrm{~mm}-45 \mathrm{~mm}$ & $25 \mathrm{~mm}$ & $45 \mathrm{~mm}$ & - & $25 \mathrm{~mm}$ \\
\hline Başlama bölümü uzunluğu & $\geq 350 \mathrm{~mm}$ & $500 \mathrm{~mm}$ & Platform & - & $700 \mathrm{~mm}$ \\
\hline Başlama bölümü eğimi & $0^{\circ}-5^{\circ}$ & $5,4^{\circ}$ & $\begin{array}{l}\text { başlama bölümü } \\
\text { olarak } \\
\text { kullanıldığından }\end{array}$ & - & $2,4^{\circ}$ \\
\hline Yan koruma yüksekliği & $\geq 500 \mathrm{~mm}$ & $\geq 550 \mathrm{~mm}$ & $\begin{array}{l}\text { değerlendiril- } \\
\text { memiştir. }\end{array}$ & - & $520 \mathrm{~mm}$ \\
\hline Kayma bölümü çap1 & $\geq 750 \mathrm{~mm}$ & - & - & $750 \mathrm{~mm}$ & - \\
\hline Kayma bölümü derinliği & $\begin{array}{l}\geq 100 \mathrm{~mm} \\
<700 \mathrm{~mm} \text { veya }>900 \mathrm{~mm}\end{array}$ & $185 \mathrm{~mm}$ & $170 \mathrm{~mm}$ & - & $215 \mathrm{~mm}$ \\
\hline Kayma bölümü genişliği & $\begin{array}{l}\text { Spiral için } \\
<700 \mathrm{~mm}\end{array}$ & $465 \mathrm{~mm}$ & $405 \mathrm{~mm}$ & - & $520 \mathrm{~mm}$ \\
\hline $\begin{array}{l}\text { Kayma bölümü ortalama } \\
\text { eğimi }\end{array}$ & $\leq 40^{\circ}$ & $30,3^{\circ}$ & $32,7^{\circ}$ & $36,3^{\circ}$ & $35,7^{\circ}$ \\
\hline Orta ayraç yüksekliği & $\geq 100 \mathrm{~mm}$ & - & $150 \mathrm{~mm}$ & - & - \\
\hline Çıkış bölümü uzunluğu & $\begin{array}{l}>300 \mathrm{~mm} \\
\text { Tünel ve spiral kaydırak } \\
\text { için: }>500 \mathrm{~mm}\end{array}$ & $420 \mathrm{~mm}$ & $545 \mathrm{~mm}$ & $560 \mathrm{~mm}$ & $470 \mathrm{~mm}$ \\
\hline Çıkış bölümü eğimi & $\leq 10^{\circ}$ & $0,4^{\circ}$ & Ters yöne $0,6^{\circ}$ & $\begin{array}{l}\text { Ters yöne } \\
0,05^{\circ}\end{array}$ & $5,5^{\circ}$ \\
\hline Çıkış bölümü yüksekliği & $\begin{array}{l}\leq 200 \mathrm{~mm} \text {, Tünel ve spiral } \\
\text { kaydırak için: } \leq 350 \mathrm{~mm}\end{array}$ & $195 \mathrm{~mm}$ & $160 \mathrm{~mm}$ & $270 \mathrm{~mm}$ & $260 \mathrm{~mm}$ \\
\hline
\end{tabular}

Tablo 4. Standart değerler ve İnebolu Parkı atlıkarınca ölçüleri

\begin{tabular}{lll}
\hline Ölçüm yeri & Olması gereken & Ölçülen \\
\hline Serbest düşme yüksekliği & $\leq 1000 \mathrm{~mm}$ & $640 \mathrm{~mm}$ \\
Darbe alanı & $\geq 2000 \mathrm{~mm}$ & $<2000 \mathrm{~mm}$ \\
Eksen eğimi & $\leq 5^{\circ}$ & $0,8^{\circ}$ \\
Hız & $\leq 5 \mathrm{~m} / \mathrm{sn}$ & $1,8 \mathrm{~m} / \mathrm{sn}$ \\
Kavramalar & $16 \mathrm{~mm}-45 \mathrm{~mm}$ & $28 \mathrm{~mm}$ ve $30 \mathrm{~mm}$ \\
\hline
\end{tabular}

Tahterevalli ile ilgili olarak tespit edilen uygunsuzluklar; darbe alanı ölçüsü, oturak eğimi, yerden yükseklik, polietilen aksamın yan görünüşleri ve deformasyon olması ve ahşap malzemenin zeminle bağlantısının kesilmesi olarak belirlenmiştir. Olumlu bulunan yönler ise serbest düşme yüksekliği, yanal sapma, el desteklerinin kalınlığı ve göz yakalanmasına sebebiyet vermeyecek şekilde tasarlanmış olması, mafsallarda sıkıştırma etkisi bulunmaması, taşıyıcı aksamın gövde yakalanmasına sebebiyet vermeyecek şekilde tasarlanmış olması şeklinde sıralanabilmektedir (Tablo 5).

Oyun alanı genel olarak değerlendirildiğinde, darbe alanlarının standartta belirtilen değerlerden daha küçük olduğu saptanmıştır. Birbirinden bağımsız olarak alana konumlandırılmış olan oyun donanımının güvenli kullanımı için yeterli alan bulunmamakta, elemanların darbe alanları üst üste binmektedir. Örneğin kaydıraktan kayan bir çocuğun, atlıkarıncadan atlayarak uzaklaşan bir çocukla çarpışma ihtimali çok yüksektir. Buna ek olarak oyun alanını sınırlayan duvarlar ve yetişkin gözetimi için yerleştirilmiş oturma alanı da yine oyun donanımının darbe alanı içinde kalmaktadır. 
Tablo 5. Standart değerler ve İnebolu Parkı tahterevalli ölçüleri

\begin{tabular}{lll}
\hline Ölçüm yeri & Olması gereken & Ölçülen \\
\hline Serbest düşme yüksekliği & $\leq 1500 \mathrm{~mm}$ & $1275 \mathrm{~mm}$ \\
Darbe alanı & $\geq 2000 \mathrm{~mm}$ & $<2000 \mathrm{~mm}$ \\
Oturak eğimi & $\leq 20^{\circ}$ & $26,3^{\circ}$ \\
Yanal sapma & $\leq 140 \mathrm{~mm}$ & $75 \mathrm{~mm}$ \\
Kavramalar & $16 \mathrm{~mm}-45 \mathrm{~mm}$ & $36 \mathrm{~mm}$ \\
\hline
\end{tabular}

Oyun alanı genel olarak değerlendirildiğinde, darbe alanlarının standartta belirtilen değerlerden daha küçük olduğu saptanmıştır. Birbirinden bağımsız olarak alana konumlandırılmış olan oyun donanımının güvenli kullanımı için yeterli alan bulunmamakta, elemanların darbe alanları üst üste binmektedir. Örneğin kaydıraktan kayan bir çocuğun, atlıkarıncadan atlayarak uzaklaşan bir çocukla çarpışma ihtimali çok yüksektir. Buna ek olarak oyun alanını sınırlayan duvarlar ve yetişkin gözetimi için yerleştirilmiş oturma alanı da yine oyun donanımının darbe alanı içinde kalmaktadır.

Oyun alanı zemininde kauçuk kaplama malzemesi kullanılmıştır. Ancak kullanılan döşemenin, hangi serbest düşme yüksekliği için uygun olduğu tespit edilememiştir.

\subsection{Füsun Sayek Parkı}

Füsun Sayek Parkı'nda bulunan oyun elemanının taşıyıcı aksamı metal malzemeden üretilmiştir. Kaydırak ve çatıda polietilen malzeme kullanıldığı saptanmıştır.

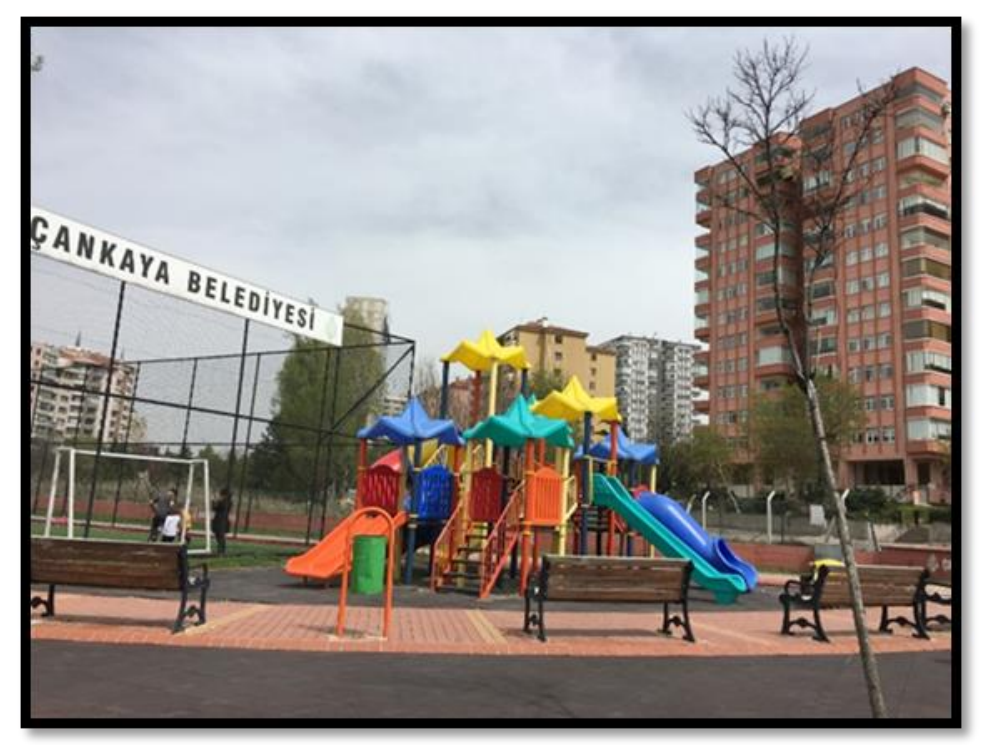

Şekil 5. Füsun Sayek Parkı oyun alanı

Oyun donanımının genel güvenlik standardı TS EN 1176-1 kapsamında yapılan değerlendirmede, çatı yüksekliklerinin standartta verilen alt sınırın altında, korkuluk yüksekliklerinin de üst sınırın üstünde olduğu tespit edilmiştir (Tablo 6). Ayrıca, korkuluk birleşme yerlerinde baş boyun yakalama riski olduğu tespit edilmiştir.

Basamak sayısı, basamak kalınlığı ve merdiven yatay eğiminin standartta verilen değerleri sağladığ1 saptanmıştır. Merdivenlerde bulunan tırabzanların yükseklik ve kalınlık yönleriyle standarda uygun olduğu tespit edilmiştir. 
Tablo 6. Standart değerler ve Füsun Sayek Parkı kaydırak donanımı genel ölçüler

\begin{tabular}{lll}
\hline Ölçüm yeri & Olması gereken & Ölçülen \\
\hline Basamak kalınlığı & $\leq 60 \mathrm{~mm}$ & $35 \mathrm{~mm}$ \\
Merdiven yatay eğimi & $\leq 3^{\circ}$ & $0,9^{\circ}$ \\
Tirabzan yüksekliği & $600 \mathrm{~mm}-850 \mathrm{~mm}$ & $735 \mathrm{~mm}$ \\
Tirabzan kavrama kalınlığı & $16 \mathrm{~mm}-45 \mathrm{~mm}$ & $21 \mathrm{~mm}$ ve $32 \mathrm{~mm}$ \\
Çatı yükseklikleri & $\geq 1800 \mathrm{~mm}$ & $1370 \mathrm{~mm}$ ila $2200 \mathrm{~mm}$ \\
Korkuluk yükseklikleri & $600 \mathrm{~mm}-850 \mathrm{~mm}$ & $970 \mathrm{~mm}$ \\
Darbe alanları & $\geq 2000 \mathrm{~mm}$ & $1900 \mathrm{~mm}$ ve $1060 \mathrm{~mm}$ \\
\hline
\end{tabular}

Kaydıraklarla ilgili ölçümler Tablo 7'de verilmiştir. Buna göre; başlama bölümü bulunmayan çoklu bağlı kaydırağın kayma bölümü derinliği, genişliği, ortalama eğimi ile orta ayraç yüksekliğinin standarda uygun olduğu tespit edilmiştir. Çıkış bölümü ise uzunluk değeri hariç (eğim ve yükseklik açısından) standarda uygundur.

Tablo 7. Standart değerler ve Füsun Sayek Parkı kaydırak ölçüleri

\begin{tabular}{|c|c|c|c|c|c|c|c|}
\hline \multicolumn{2}{|l|}{ Ölçüm yeri } & \multirow{2}{*}{$\begin{array}{l}\text { Olması gereken } \\
600 \mathrm{~mm}-900 \mathrm{~mm}\end{array}$} & \multirow{2}{*}{$\begin{array}{l}\begin{array}{l}\text { Ölçülen } \\
\text { Çoklu Bağlı } \\
\text { Kaydırak }\end{array} \\
-\end{array}$} & \multirow{2}{*}{$\begin{array}{l}\begin{array}{l}\text { Ölçülen } \\
\text { Bağlı } \\
\text { Kaydırak }\end{array} \\
740 \mathrm{~mm}\end{array}$} & \multirow{2}{*}{$\begin{array}{l}\begin{array}{l}\text { Ölçülen } \\
\text { Spiral } \\
\text { Kaydırak }\end{array} \\
850 \mathrm{~mm}\end{array}$} & \multirow{2}{*}{$\begin{array}{l}\begin{array}{l}\text { Ölçülen } \\
\text { Tünel } \\
\text { Kaydırak }\end{array} \\
-\end{array}$} & \multirow{2}{*}{$\begin{array}{l}\text { Ölçülen } \\
\text { Karışık } \\
\text { Tünel } \\
\text { Kaydırak } \\
-\end{array}$} \\
\hline $\begin{array}{l}\text { Tutma } \\
\text { yüksekliği }\end{array}$ & çubuğu & & & & & & \\
\hline $\begin{array}{l}\text { Tutma } \\
\text { kavrama }\end{array}$ & çubuğu & $16 \mathrm{~mm}-45 \mathrm{~mm}$ & - & $27 \mathrm{~mm}$ & $32 \mathrm{~mm}$ & - & - \\
\hline $\begin{array}{l}\text { Başlama } \\
\text { uzunluğu }\end{array}$ & bölümü & $\geq 350 \mathrm{~mm}$ & - & $380 \mathrm{~mm}$ & $700 \mathrm{~mm}$ & - & - \\
\hline $\begin{array}{l}\text { Başlama } \\
\text { eğimi }\end{array}$ & bölümü & $0^{\circ}-5^{\circ}$ & - & $2,9^{\circ}$ & $3,9^{\circ}$ & - & - \\
\hline $\begin{array}{l}\text { Yan } \\
\text { yüksekliği }\end{array}$ & koruma & $\geq 500 \mathrm{~mm}$ & - & $480 \mathrm{~mm}$ & $505 \mathrm{~mm}$ & - & - \\
\hline \multicolumn{2}{|c|}{ Kayma bölümü çapı } & $\geq 750 \mathrm{~mm}$ & - & - & - & $<750 \mathrm{~mm}$ & $<750 \mathrm{~mm}$ \\
\hline $\begin{array}{l}\text { Kayma } \\
\text { derinliği }\end{array}$ & bölümü & $\begin{array}{l}\geq 100 \mathrm{~mm} \\
\text { Spiral kaydırak } \\
\text { için } \geq 150 \mathrm{~mm} \\
<700 \mathrm{~mm} \text { veva > }\end{array}$ & $170 \mathrm{~mm}$ & $180 \mathrm{~mm}$ & $200 \mathrm{~mm}$ & - & - \\
\hline $\begin{array}{l}\text { Kayma } \\
\text { genişliği }\end{array}$ & bölümü & $\begin{array}{l}900 \mathrm{~mm} \\
\text { Spiral kaydırak } \\
\text { için }<700 \mathrm{~mm}\end{array}$ & $400 \mathrm{~mm}$ & $430 \mathrm{~mm}$ & $510 \mathrm{~mm}$ & - & - \\
\hline $\begin{array}{l}\text { Kayma } \\
\text { ortalama e }\end{array}$ & $\begin{array}{l}\text { bölümü } \\
\text { imi }\end{array}$ & $\leq 40^{\circ}$ & $33,15^{\circ}$ & $36,46^{\circ}$ & $34,9^{\circ}$ & $41,5^{\circ}$ & $26,6^{\circ}$ \\
\hline $\begin{array}{l}\text { Orta } \\
\text { yüksekliği }\end{array}$ & ayraç & $\geq 100 \mathrm{~mm}$ & $100 \mathrm{~mm}$ & - & - & - & - \\
\hline $\begin{array}{l}\text { Çıkış } \\
\text { uzunluğu }\end{array}$ & bölümü & $>500 \mathrm{~mm}$ & $345 \mathrm{~mm}$ & $480 \mathrm{~mm}$ & $430 \mathrm{~mm}$ & $570 \mathrm{~mm}$ & $585 \mathrm{~mm}$ \\
\hline Çıkış bölüm & ü eğimi & $\leq 10^{\circ}$ & $4^{\circ}$ & $0,6^{\circ}$ & $3,3^{\circ}$ & $3,9^{\circ}$ & $0,5^{\circ}$ \\
\hline $\begin{array}{l}\text { Çıkış } \\
\text { yüksekliği }\end{array}$ & bölümü & $\leq 350 \mathrm{~mm}$ & $275 \mathrm{~mm}$ & $245 \mathrm{~mm}$ & $320 \mathrm{~mm}$ & $170 \mathrm{~mm}$ & $285 \mathrm{~mm}$ \\
\hline
\end{tabular}

Bağlı kaydırağın, başlama bölümü uzunluğu, eğimi, yan koruma yüksekliği ve tutma çubuğunun yükseklik ve 
kalınlık değerleri ile kayma bölümü derinliği, genişliği ve ortalama eğimi standarda uygun olarak değerlendirilmiştir. Çıkış bölümünün eğimi ve yüksekliğinin standarda uygun olduğu ancak uzunluğunun standarda uymadığı tespit edilmiştir.

Spiral kaydırağın başlama bölümü uzunluğu, eğimi, yan koruma yüksekliği ve tutma çubuğunun yükseklik ve kalınlık değerleri ile kayma bölümü derinliği, genişliği ve ortalama eğiminin standarda uygun olduğu tespit edilmiştir. Çıkış bölümünün eğimi ve yüksekliğinin standarda uygun ancak uzunluğunun standarda uygun olmadığı saptanmıştır.

Hem tünel kaydırağın hem de karışık tünel kaydırağın çapı standartta verilen değerin altındadır. Bu da tüm vücudun yakalanmasına sebebiyet verebilir. Buna ek olarak karışık tünel kaydırağın kayma bölümü ortalama eğimi standarda uygun ancak tünel kaydırağın ortalama eğimi standartta verilen değerin üstündedir. Her iki kaydırağın da çıkış bölümü uzunluğu, eğimi ve yüksekliğinin standarda uygun olduğu tespit edilmiştir.

Ölçümleri yapılan oyun alanının, darbe alanlarını sağlayacak büyüklükte bir alana konumlandırılmadığı, kaydırak çıkış kısımlarının oyun alanını çevreleyen beton bordürlerle bitişik olduğu saptanmıştır.

Oyun alanı zemininde kauçuk kaplama malzemesi kullanılmıştır. Ancak kullanılan döşemenin, hangi serbest düşme yüksekliği için uygun olduğu tespit edilememiştir.

\section{3. Öysekent Doğa Parkı}

Öysekent Doğa Parkı'nda yer alan oyun elemanlarında taşıyıcı aksam metal malzemeden üretilmiştir. Çatı, kaydırak, salıncak oturağında ise polietilen malzeme kullanılmıştır (Şekil 6).

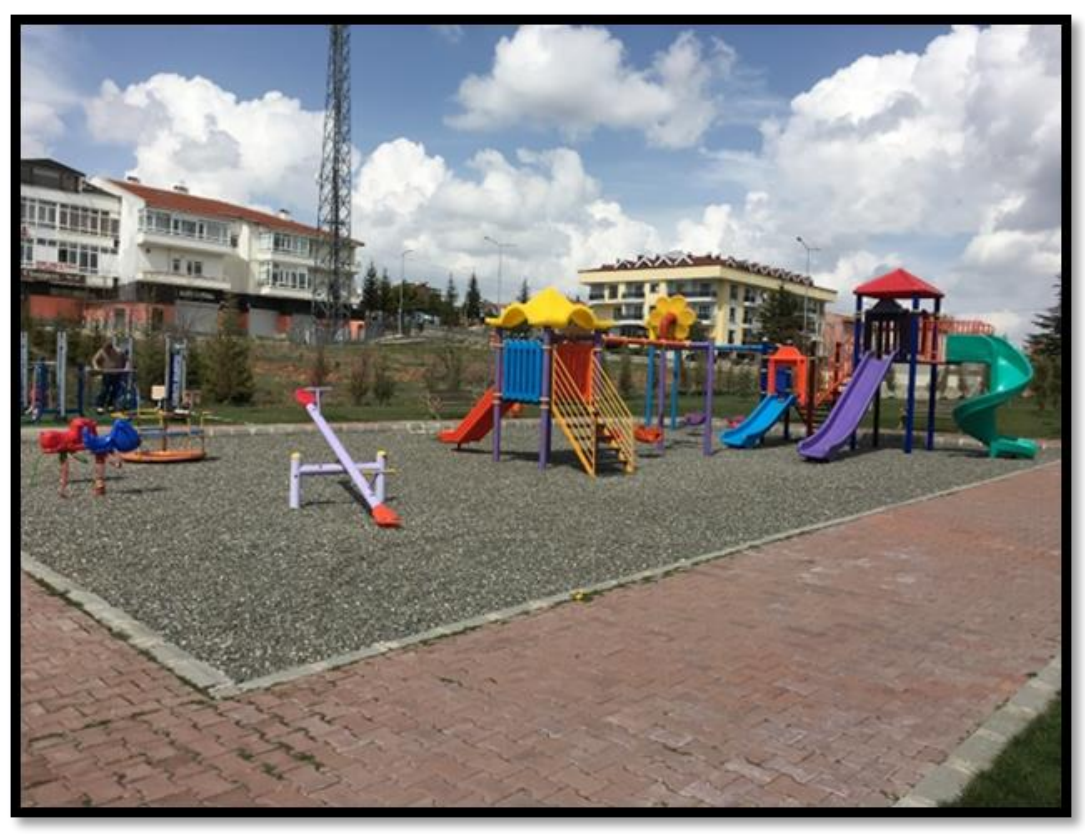

Şekil 6. Öysekent Doğa Parkı oyun alanı

Her iki kaydırak donanımının genel güvenlik standardı çerçevesinde irdelenmesi sonucunda, basamak sayıları ve eğiminin uygun olduğu tespit edilmiştir. Basamaklar üzerinde tesis edilmiş olan tırabzanların yükseklikleri ve kalınlıklarının standartta verilen aralıkta olduğu görülmüştür. Çatı yükseklikleri ve darbe alanlarının olması gereken değerlerin altında olduğu saptanmıştır. Küçük oyun donanımında bulunan polietilen pano korkuluk yüksekliğinin standartta verilen üst sınırdan fazla olduğu görülmüştür (Tablo 8).

Büyük oyun grubuna bağlı kaydıraklar ile küçük oyun modeline bağlı kaydırak ile ilgili ölçüler Tablo 9'da verilmiştir. 
Tablo 8. Standart değerler ve Öysekent Doğa Parkı kaydırak donanımı genel ölçüler

\begin{tabular}{|c|c|c|c|}
\hline Ölçüm yeri & Olması gereken & $\begin{array}{l}\text { Ölçülen } \\
\text { Büyük Modül }\end{array}$ & $\begin{array}{l}\text { Ölçülen } \\
\text { Küçük Modül }\end{array}$ \\
\hline Basamak sayısı & $\geq 3$ & 5 & 5 \\
\hline Basamak yatay eğimi & $\leq 3^{\circ}$ & $0,9^{\circ}$ & $1,5^{\circ}$ \\
\hline Tirabzan yüksekliği & $600 \mathrm{~mm}-850 \mathrm{~mm}$ & $705 \mathrm{~mm}$ & $825 \mathrm{~mm}$ \\
\hline $\begin{array}{l}\text { Tirabzan kavrama } \\
\text { kalınlığı }\end{array}$ & $16 \mathrm{~mm}-45 \mathrm{~mm}$ & $43 \mathrm{~mm}$ ve $44 \mathrm{~mm}$ & $27 \mathrm{~mm}$ \\
\hline Çatı yüksekliği & $\geq 1800 \mathrm{~mm}$ & $1650 \mathrm{~mm}$ & $1200 \mathrm{~mm}$ \\
\hline $\begin{array}{l}\text { Polietilen korkuluk } \\
\text { yüksekliği }\end{array}$ & $600 \mathrm{~mm}-850 \mathrm{~mm}$ & - & $1000 \mathrm{~mm}$ \\
\hline Darbe alanları & $\geq 2000 \mathrm{~mm}$ & 550 mm (en küçük) & $<2000 \mathrm{~mm}$ \\
\hline
\end{tabular}

Büyük oyun grubuna bağlı Spiral kaydırağın başlama bölümü uzunluğu, eğimi ve yan koruma yüksekliğinin standarda uygun olduğu tespit edilmiştir ancak tutma çubuğu olması gerektiği halde tutma çubuğu bulunmamaktadır. Kayma bölümü derinliği ve genişliği uygun olduğu ancak ortalama eğimin standartta verilen değeri aştı̆̆1 saptanmıştır. Çıkış bölümü eğimi ve yüksekliğinin standarda uygun olduğu ancak gerekli uzunluğun sağlanmadığı görülmüştür.

Büyük oyun grubunda yer alan her iki kaydırakta da platform başlama bölümü olarak kullanıldığından başlama bölümü ile ilgili kurallar değerlendirme dışı bırakılmıştır. Her iki kaydırağın da kayma bölümü derinliği, genişliği ve ortalama eğiminin standartlarda verilen değerlere uygun olduğu tespit edilmiştir. Çıkış bölümü uzunluğu her iki kaydırak için de olumsuz olarak değerlendirilmiş olup çıkış eğimi ve çıkış yükseklikleri uygundur. Platform yüksekliği $1 \mathrm{~m}$ olan bağlı kaydırağın kayma bölümünün başında yer alan pano şeklindeki bariyer yüksekliğinin standartta belirtilen aralığı sağladığı görülmüştür.

Tablo 9. Standart değerler ve Öysekent Doğa Parkı kaydırak ölçüleri

\begin{tabular}{|c|c|c|c|c|c|}
\hline \multirow{2}{*}{ Ölçüm yeri } & \multirow{2}{*}{$\begin{array}{l}\text { Olması } \\
\text { gereken }\end{array}$} & \multicolumn{3}{|l|}{$\begin{array}{l}\text { Ölçülen } \\
\text { Büyükk Modül }\end{array}$} & \multirow{2}{*}{$\begin{array}{l}\text { Ölçülen } \\
\text { Küçük Modül } \\
\text { Bağlı Kaydırak }\end{array}$} \\
\hline & & $\begin{array}{l}\text { Spiral Kaydırak } \\
(1,97 \mathrm{~m})\end{array}$ & $\begin{array}{l}\text { Bağlı Kaydırak } \\
(1,97 \mathrm{~m})\end{array}$ & $\begin{array}{l}\text { Bağlı Kaydırak } \\
\text { (1 m) }\end{array}$ & \\
\hline $\begin{array}{l}\text { Tutma } \\
\text { çubuğu } \\
\text { yüksekliği }\end{array}$ & $\begin{array}{l}600 \mathrm{~mm}-900 \\
\mathrm{~mm}\end{array}$ & - & & & $805 \mathrm{~mm}$ \\
\hline $\begin{array}{l}\text { Tutma } \\
\text { çubuğu } \\
\text { kavrama }\end{array}$ & $\begin{array}{l}16 \mathrm{~mm}-45 \\
\mathrm{~mm}\end{array}$ & - & $\begin{array}{l}\text { Platform } \\
\text { başlama bölümü } \\
\text { olarak }\end{array}$ & $\begin{array}{l}\text { Platform } \\
\text { başlama bölümü } \\
\text { olarak }\end{array}$ & $27 \mathrm{~mm}$ \\
\hline $\begin{array}{l}\text { Başlama } \\
\text { bölümü } \\
\text { uzunluğu }\end{array}$ & $\geq 350 \mathrm{~mm}$ & $800 \mathrm{~mm}$ & $\begin{array}{l}\text { kullanıldığından } \\
\text { değerlendirilme- } \\
\text { miştir. }\end{array}$ & $\begin{array}{l}\text { kullanıldığından } \\
\text { değerlendirilme- } \\
\text { miştir. }\end{array}$ & $400 \mathrm{~mm}$ \\
\hline $\begin{array}{l}\text { Başlama } \\
\text { bölümü } \\
\text { eğimi }\end{array}$ & $0^{\circ}-5^{\circ}$ & $1,3^{\circ}$ & & & $6,7^{\circ}$ \\
\hline
\end{tabular}


Tablo 9. Devam ediyor

\begin{tabular}{|c|c|c|c|c|c|}
\hline \multirow[b]{2}{*}{ Ölçüm yeri } & \multirow[b]{2}{*}{$\begin{array}{l}\text { Olması } \\
\text { gereken }\end{array}$} & \multicolumn{3}{|c|}{$\begin{array}{l}\text { Ölçülen } \\
\text { Büyük Modül }\end{array}$} & \multirow{2}{*}{$\begin{array}{l}\text { Ölçülen } \\
\text { Küçük Modül } \\
\text { Bağlı } \\
\text { Kaydırak }\end{array}$} \\
\hline & & $\begin{array}{l}\text { Spiral } \\
\text { Kaydırak } \\
(\mathbf{1 , 9 7 m )}\end{array}$ & $\begin{array}{l}\text { Bağlı } \\
\text { Kaydırak } \\
(1,97 m)\end{array}$ & $\begin{array}{l}\text { Bağlı } \\
\text { Kaydırak } \\
(1 \text { m) }\end{array}$ & \\
\hline $\begin{array}{l}\text { Yan koruma } \\
\text { yüksekliği }\end{array}$ & $\geq 500 \mathrm{~mm}$ & $500 \mathrm{~mm}$ & & & $520 \mathrm{~mm}$ \\
\hline $\begin{array}{l}\text { Kayma bölümü } \\
\text { derinliği }\end{array}$ & $\geq 150 \mathrm{~mm}$ & $210 \mathrm{~mm}$ & $185 \mathrm{~mm}$ & $190 \mathrm{~mm}$ & $180 \mathrm{~mm}$ \\
\hline \multirow{3}{*}{$\begin{array}{l}\text { Kayma bölümü } \\
\text { genişliği }\end{array}$} & $<700 \mathrm{~mm}$ veya & & & & \\
\hline & $>900 \mathrm{~mm}$ & & & & \\
\hline & $\begin{array}{l}\text { Spiral kaydırak } \\
\text { için } \\
<700 \mathrm{~mm}\end{array}$ & $580 \mathrm{~mm}$ & $460 \mathrm{~mm}$ & $450 \mathrm{~mm}$ & $430 \mathrm{~mm}$ \\
\hline $\begin{array}{l}\text { Kayma bölümü } \\
\text { ortalama eğimi }\end{array}$ & $\leq 40^{\circ}$ & $40,2^{\circ}$ & $34,3^{\circ}$ & $27,9^{\circ}$ & $38,5^{\circ}$ \\
\hline $\begin{array}{l}\text { Çıkış bölümü } \\
\text { uzunluğu }\end{array}$ & $>500 \mathrm{~mm}$ & $425 \mathrm{~mm}$ & $395 \mathrm{~mm}$ & $425 \mathrm{~mm}$ & $505 \mathrm{~mm}$ \\
\hline $\begin{array}{l}\text { Çıkış bölümü } \\
\text { eğimi }\end{array}$ & $\leq 10^{\circ}$ & $4,9^{\circ}$ & $6,5^{\circ}$ & $4,5^{\circ}$ & $3,1^{\circ}$ \\
\hline $\begin{array}{l}\text { Çıkış bölümü } \\
\text { yüksekliği }\end{array}$ & $\leq 350 \mathrm{~mm}$ & $100 \mathrm{~mm}$ & $200 \mathrm{~mm}$ & $170 \mathrm{~mm}$ & $245 \mathrm{~mm}$ \\
\hline $\begin{array}{l}\text { Bariyer } \\
\text { yüksekliği }\end{array}$ & $\begin{array}{l}600 \mathrm{~mm}- \\
900 \mathrm{~mm}\end{array}$ & & & $795 \mathrm{~mm}$ & \\
\hline
\end{tabular}

Küçük oyun grubunda yer alan bağlı kaydırağın tutma çubuğu yüksekliği ve kalınlığı, başlama bölümü uzunluğu ve yan koruma yüksekliğinin standarda uygun olduğu ancak başlama bölümü eğiminin standartta verilen değerden fazla olduğu tespit edilmiştir. Kaydırağın kayma bölümü derinliği, genişliği, ortalama eğimi ile çıkış bölümü uzunluğu, eğimi ve yüksekliğinin standarda uygun olduğu saptanmıştır.

Salıncaklar genel olarak ele alındığında; salıncağın kaydırağa bitişik olması, keskin çıkıntılar ve kısmi paslanmalar olması, aralıklarda parmak yakalama riski olması, darba alanlarının gerekli ölçüleri sağlamaması yönleri ile standartlara uygun olmadığı değerlendirilmiştir (Tablo 10).

Standartlar kapsamında incelenen oyun alanında darbe alanlarını sağlayacak şekilde bir alana konumlandırılmadığı tespit edilmiştir. Ayrıca salıncak ile kaydırağın birlikte kullanıldığı durumda iki donanım arasında yeterli mesafe bırakılmamış, darbe alanlarının çakışmaması gerekliliği göz ardı edilmiştir.

Atlıkarınca genel olarak ele alındığında; serbest düşme yüksekliği, eksen eğimi, hız, kavramalar ve el çarkı tasarımı yönünden uygun iken, darbe alanı ölçüleri, parmak yakalama riski taşıması, platform ile zemin arasındaki mesafe ve üst yapıların platformdan dışarı taşması yönüyle uygun olmadığı değerlendirilmiştir (Tablo 11). 
Tablo 10. Standart değerler ve Öysekent Doğa Parkı salıncak ölçüleri

\begin{tabular}{|c|c|c|c|}
\hline Ölçüm yeri & $\begin{array}{l}\text { Hesaplanan } \\
\text { (olması gereken) }\end{array}$ & $\begin{array}{l}\text { Ölçülen } \\
\text { Büyük gruba bağlı } \\
\text { salıncak }\end{array}$ & $\begin{array}{l}\text { Ölçülen } \\
\text { Küçük gruba bağlı } \\
\text { salıncak }\end{array}$ \\
\hline $\begin{array}{l}\text { Salıncak oturağı ile bitişik } \\
\text { yapı arasındaki mesafe } \\
\text { ( C ) }\end{array}$ & $\begin{array}{l}\text { Büyük gruba bağlı için; } \\
\geq 547 \mathrm{~mm} \\
\text { Küçük gruba bağlı için; } \\
\geq 538 \mathrm{~mm}\end{array}$ & 710 & 730 \\
\hline $\begin{array}{l}\text { İki salıncak oturağı } \\
\text { arasındaki mesafe ( S ) }\end{array}$ & $\begin{array}{l}\text { Büyük gruba bağlı için; } \\
\geq 647 \mathrm{~mm} \\
\text { Küçük gruba bağlı için: } \\
\geq 638 \mathrm{~mm}\end{array}$ & 770 & 680 \\
\hline $\begin{array}{l}\text { Zincirin taşıyıcı eksene } \\
\text { bağlantı noktaları } \\
\text { arasındaki mesafe ( F ) }\end{array}$ & $\begin{array}{l}\text { Büyük gruba bağlı için; } \\
\geq 521,75 \mathrm{~mm} \\
\text { Küçük gruba bağlı için: } \\
\geq 514,5 \mathrm{~mm}\end{array}$ & 500 & 545 \\
\hline Yerden yükseklik & $\geq 350 \mathrm{~mm}$ & $320 \mathrm{~mm}$ & $355 \mathrm{~mm}$ \\
\hline Serbest düşme yüksekliği & $\leq 1500 \mathrm{~mm}$ & $1227,5 \mathrm{~mm}$ & $1235 \mathrm{~mm}$ \\
\hline Zincir özellikleri / kavrama & $\begin{array}{l}6 \mathrm{~mm} \text { kalibre zincir / } \\
16 \mathrm{~mm}-45 \mathrm{~mm}\end{array}$ & $\begin{array}{l}6 \mathrm{~mm} \text { kalibre zincir } / 20 \\
\mathrm{~mm}\end{array}$ & $\begin{array}{l}6 \mathrm{~mm} \text { kalibre zincir } \\
/ 17 \mathrm{~mm}\end{array}$ \\
\hline
\end{tabular}

Tablo 11. Standart değerler ve Öysekent Doğa Parkı atlıkarınca ölçüleri

\begin{tabular}{lll}
\hline Ölçüm yeri & Olması gereken & Ölçülen \\
\hline Serbest düşme yüksekliği & $\leq 1000 \mathrm{~mm}$ & $120 \mathrm{~mm}$ \\
Darbe alanı & $\geq 2000 \mathrm{~mm}$ & $<2000 \mathrm{~mm}$ \\
Eksen eğimi & $\leq 5^{\circ}$ & $1,1^{\circ}$ \\
Hız & $\leq 5 \mathrm{~m} / \mathrm{sn}$ & $1,96 \mathrm{~m} / \mathrm{sn}$ \\
Kavramalar & $16 \mathrm{~mm}-45 \mathrm{~mm}$ & $23 \mathrm{~mm}$ \\
\hline
\end{tabular}

Serbest düşme yüksekliği, el desteklerinin kalınlığı ve yanal sapma yönünden uygun olan tahterevalli, darbe alanı, oturak eğimi, zeminle oturak arasındaki mesafe, mafsallardaki sıkıştırma etkisi, göz yakalama riski taşıması ile önde ve arkada çıkıntı yapan kısımların uygun yarıçapta olmaması yönünden ilgili standarda aykırı olarak değerlendirilmiştir (Tablo 12).

Tablo 12. Standart değerler ve Öysekent Doğa Parkı tahterevalli ölçüleri

\begin{tabular}{lll}
\hline Ölçüm yeri & Olması gereken & Ölçülen \\
\hline Serbest düşme yüksekliği & $\leq 1500 \mathrm{~mm}$ & $1250 \mathrm{~mm}$ \\
Darbe alanı & $\geq 2000 \mathrm{~mm}$ & $<2000 \mathrm{~mm}$ \\
Oturak eğimi & $\leq 20^{\circ}$ & $23,5^{\circ}$ \\
Yanal sapma & $\leq 140 \mathrm{~mm}$ & $93 \mathrm{~mm}$ \\
Kavramalar & $16 \mathrm{~mm}-45 \mathrm{~mm}$ & $41 \mathrm{~mm}$ \\
\hline
\end{tabular}


Standartta tek noktaya bağlı sallanma elemanı olarak tanımlanan ve kullanıcılar tarafindan zıp zıp olarak adlandırılan oyun donanımı genel olarak irdelendiğinde; serbest düşme yüksekliği, oturak eğimi, el desteklerinin kalınlığı, ayak dayama yerleri yönüyle uygun olarak değerlendirilirken, darbe alanı ölçüsü, yaydaki sıkışma, el desteklerinde göz yakalama riski bulunması ile önde ve arkada çıkıntı yapan kısımların uygun yarıçapta olmaması yönleri ile ilgili standarda aykırı olarak değerlendirilmiştir (Tablo 13).

Tablo 13. Standart değerler ve Öysekent Doğa Parkı sallanma elemanı ölçüleri

\begin{tabular}{lll}
\hline Ölçüm yeri & Olması gereken & Ölçülen \\
\hline Serbest düşme yüksekliği & $\leq 1500 \mathrm{~mm}$ & $570 \mathrm{~mm}$ \\
Darbe alanı & $\geq 1500 \mathrm{~mm}$ & $<1500 \mathrm{~mm}$ \\
Oturak eğimi & $\leq 30^{\circ}$ & $21,1^{\circ}$ \\
Yaydaki sıkışma & $\leq \% 5$ & $\% 12,5$ \\
El destekleri kavramalar & $16 \mathrm{~mm}-45 \mathrm{~mm}$ & $27 \mathrm{~mm}$ \\
\hline
\end{tabular}

Oyun alanının zemininde çakıl kullanılmıştır. Genel güvenlik standardına göre; 2mm ila 8mm tane büyüklüğüne sahip çakılın $200 \mathrm{~mm}$ derinlikte uygulanması durumunda kritik düşme yüksekliği en fazla $2000 \mathrm{~mm}, 300 \mathrm{~mm}$ derinlikte uygulanması durumunda kritik düşme yüksekliği en fazla 3000mm olabilmektedir. Ancak oyun alan zeminindeki çakılın derinlik ile ilgili bu koşulu sağlamadığı tespit edilmiştir.

\section{Sonuç ve Öneriler}

Kamusal alanda kurulmuş olan oyun alanlarının güvenli olup olmadığının değerlendirilmesi amacı ile Ankara İli, Çankaya İlçesi sınırları içinde yer alan 3 parkta bulunan oyun alanlarındaki oyun donanımı Avrupa Standartları göz önünde bulundurularak incelenmiş ve değerlendirilmiştir. Karşılaştırılan oyun alanlarının oyun çeşitliliği açısından birbirinden farklı olmadığı görülmüştür. Üretilen oyun alanı donanımının, emprenye ahşap, çelik, galvanizli çelik, kauçuk ve polietilen malzemelerin en az iki veya daha fazlasını içerdiği tespit edilmiştir.

Oyun donanımın standartlara ölçü ve boyut yönüyle uygunluğunun irdelendiği bu çalışma göstermiş̧tir ki, kamusal alanda bulunan oyun alanları ve bu alanlar içindeki oyun donanımı, çocukların öngöremeyeceği riskleri ortadan kaldırmak amacıyla kullanılan ilgili güvenlik ve ürün standartlarının gereklerini karşılamamakta ve birçok açıdan tehlike yaratmaktadır.

İncelenen oyun alanı elemanlarında;

- Darbe alanı ölçülerine uymayan boyutlarda boşluklar,

- Elemanların farklı noktalarında yakalanmalar (baş/boyun, parmak, saç/giysi),

- Çıkıntı yapan sivri kısımların bulunması (8mm’den büyük vida uçları vb.),

- Düşmeye karşı koruma elemanlarının ölçülerinde ve tasarımında standartlarla uyumsuzluk olması,

- Standartta belirtilen ölçüden daha z yüksekliğe sahip olan çatıların çarpmalara ve kafa yaralanmalarına yol açabilecek olması,

- Kaydırak çıkış kısımlarının, çocuğun kaydıraktan ayrılmasını zorlaştıracak yapıda olması (ters açı nedeniyle su birikintisi oluşması ve kaydırağın çıkış bölümünde uç kısmının uygun açı ile yuvarlatılmamış olması nedeniyle çocukların bacaklarının zarar görmesine yol açabilecek olması),

- Salıncaklarda; laboratuvar ortamında gerçekleştirilen salıncağın darbe zayıflamasının belirlenmesi amacıyla yapılan deneyden geçmediği bilinen (polietilen) oturakların kullanılması,

- Oyun alanı zemininin bakımının yapılmaması, özellikle zemin malzemesi seçilirken elemanın serbest düşme yüksekliğinin göz ardı edilmesi,

- Elemanların yapısal bütünlüğü etkileyecek tahribatların olması (örneğin salıncak zincirlerinin paslı tellerle birbirine tutturulmuş olması),

- Kismi paslanma,

- Mafsallarda sıkışma (tahterevalli),

- Temellerin açı̆̆a çıkması

gibi standart ölçü ve koşullarına uymayan unsurların bulunduğu tespit edilmiştir.

Dünya Sağlık Örgütü’nün çocuk yaralanmalarının önlenmesi konulu raporunda, Avrupa Birliği’ne üye ülkelerdeki birçok oyun alanının kötü tasarlandığı veya bakımın eksik yapıldığı ve bu durumun yaralanma riskini 
artırdığı belirtilmektedir (Sethi et. al, 2008). Oyun alanları ve yüzeyi sırasıyla EN 1176 serisi ve EN 1177 standartlarına uygun olmalıdır. Her ne kadar Avrupa Birliği, standartların uygulanmasını gönüllülük esasına göre tercihe bırakmış olsa da; Almanya, Avusturya, Belçika, Çekya, Danimarka, Fransa, Hollanda, İsveç, Macaristan, Polonya ve Yunanistan'da yasal bağlayıcılığı olan ulusal standartları bulunmaktadır (Sethi et. al, 2008).

Standartların zorunlu ve ihtiyari olarak gruplandırıldığı Türkiye'de oyun alanı elemanları ile ilgili standartlar ihtiyari (isteğe bağlı belgelendirme yapılan) standartlardır (Mecburi Standard Tebliği, 2019). Bu da oyun alanı elemanlarının bu standarda uygun üretilmesinin zorunlu olmadığı anlamını taşımaktadır. Ancak Kamu İhale Kanunu kapsamındaki kamu alımlarında, ihale şartnamelerinde standartlara uygunluk belgeleri talep edilmektedir.

Ayrıca ürünlerin standarda uygunluk belgelerinin olmasının yanında, oyun donanımının montaj ve kurulumunun standart koşulları gözetilerek gerçekleştirilmesi de önem taşımaktadır. Uygunluk belgeleri kurulum, montaj ve bakım ile ilgili faaliyetleri kapsamamakta ve bu durum standartlara göre düzenlenen belgeler üzerinde belirtilmektedir. İncelenen parklarda tespit edilen uygunsuzluklar irdelendiğinde hem oyun elemanının kendisinden hem de elemanın sahaya uygulanmasından kaynaklanan sorunlar olduğu görülmektedir. Kamusal alanda kurulmak üzere oyun alanı donanımı alımı yapan kurumlar tarafından, ihale şartı olarak ilgili standartlara göre düzenlenmiş ürün belgelerini talep edildiği ancak kabul aşamasında oyun alanının standarda uygunluğunun değerlendirilmediği, sahada tespit edilen ölçü ve boyut uygunsuzluklarından anlaşılmaktadır. Bunlara ek olarak, paslanmış parçalar, oyun alanı zeminindeki bozulmalar (su birikintisi vb.), polietilen malzemede meydana gelen deformasyon göz önüne alındığında oyun alanının işletilmesi sırasında muayene ve bakım faaliyeti yürütülmediği de anlaşılmaktadır.

Araştırma bulgularına göre, oyun alanı elemanlarında saptanan uygunsuzlukların giderilmesinde yasal düzenleme ve farkındalığı artırılması olmak üzere iki temel konu önem taşımaktadır;

Daha önce de bahsedildiği gibi oyun alanı elemanları ve zemin düzenlemelerine ilişkin standartların uygulanmasına yönelik herhangi bir zorunluluk bulunmamaktadır. Çocukların sağlığı ve can güvenliği ile doğrudan ilişkili bu standartların uygulanması konusunda ulusal bir politika geliştirilmesinin bir zorunluluk olduğu değerlendirilmektedir.

Standart koşullarını yerine getiren oyun donanımı üretmenin ve oyun alanlarının doğru kurulumunun zorunlu hale gelmesi ile standartların muayene ve bakım maddeleri dâhil tüm maddelerinin ihlali durumlarında, hazırlanacak yasal düzenlemeye göre gerekli yaptırımların uygulanmasının, çocukların oyun alanlarında güvenle oynayabilmesi açısından atılması gereken en önemli adım olacağı düşünülmektedir.

Bu çalışma kapsamında uygunsuzlukların ortadan kaldırılması için yapılan diğer tüm önerilerin, yasal düzenleme sonrasındaki süreçte gereklilik olarak kendiliğinden ortaya çıkacağı öngörülmektedir.

İncelenen tüm salıncaklarda polietilen malzemeden üretilen salıncak oturaklarının kullanıldı̆̆ saptanmıştır. Ancak, yalnızca polietilen malzemeden üretilmiş salıncak oturaklarının darbe deneyinden olumsuz sonuç aldıkları akredite laboratuvar tarafından düzenlenen muayene ve deney raporları ile kayıt altına alınmıştır. Bu kapsamda belge alabilmek amaciyla, üreticilerin oturağın söz konusu olduğu ürünler için (salıncak, oturma tipi kablolu taşıma tesisatı vb.) çeşitli ar-ge çalışmaları yürüterek oturakları darbe deneyinden geçer hale getirdikleri bilinmektedir (Yılmaz, 2018). İncelenen parklarda karşılaşılan salıncak oturaklarının belge kapsamlarında yer deneylerden olumlu sonuç alarak belge kapsamlarında yer alamayacakları açıktır. Ancak, uygunluk belgeleri kapsamında yer alan salıncak oturakları ile ihalede talep edilen veya sahada bulunan oturaklar değerlendirildiğinde, alım yapan kurumların belge kapsamı ile sahaya getirilen ürünleri karşılaştırmadığı yargısına varılmaktadır. Bu durum, aslında güvenlik yönünden onaylanmamış ürünlerin kullanıma sunulduğu anlamını taşımaktadır.

$\mathrm{Bu}$ tutarsızlığın önlenebilmesi için öncelikle ilgili uygunluk belgeleri ile birlikte teknik şartnamelerde talep edilen ürünlerin standart dışı ürünler olmasının önüne geçilmelidir. Uygulamadaki bu yanlışlığın giderilebilmesi için, teknik şartname hazırlayan uzmanların, ilgili ürün belgelerinin nasıl okunacağı ve doğru değerlendirileceği konusunda farkındalık yaratmak amacıyla eğitim süreçleri planlanmalıdır.

Yürütülen bu çalışma ile yalnızca uygunluk belgeleri üzerinden yapılan bir kontrolün, oyun alanlarını amaçlanan kalite hedefine ulaştırmayacağı açık ve net bir şekilde ortaya konmuştur. Oyun alanı elemanı tedarik süreci birden fazla aşamaya bölünerek yönetilmelidir. Alım, kabul, montaj ve işletme bu sürecin aşamaları olarak belirlenmeli ve uygulanmalıdır. Bu noktada oyun alanının kabulünü yapan uzmanların da standart koşulları ve 
belge kapsamlarının nasıl okunacağı konularında bilgilendirilmesi ve eğitilmesinin gerekliliği ortaya çıkmaktadır. Alım yapan kurumların standart şartlarına dair farkındalığının artması, üreticileri standarda uygun üretim yapmaya teşvik edecek, standardın anlaşılmasını kolaylaştıracağı gibi bu konuda bir farkındalık yaratacaktır. Faaliyet sıklığı göz önüne alındığında bu uygulamanın etkin olmayacağı düşünülüyorsa, üçünü taraf gözetim kuruluşlarından bu kapsamda hizmet alınmalıdır.

Oyun alanı tasarımı yapılırken, kurulacağı alan büyüklüğü dâhil birçok unsur göz önünde bulundurularak, donanımın yüksekliğine göre zemin kaplamasının niteliği, gerekli darbe alanı ve serbest boşlukların boyutları gibi özellikler belirlenmelidir. Bunun yanında standardın belirttiği kesin ölçülere veya boyutlara uyulması gerekmektedir. Darbe alanları, tırabzan yüksekliği, çatı yüksekliği vb. parçaların ölçülerindeki uygunsuzluklar, zemin düzenlemesinin amacına uygun şekilde yapılmamış olması gibi oyun alanı elemanının tasarım aşamasında değerlendirilmiş olması gereken, kurulu olduğu alanda düzeltilemeyecek uygunsuzlukların, ilgili standartların anlaşılması ve elemanın bu doğrultuda tasarlanması ile ortadan kolayca kaldırılabilecek durumda olduğu düşünülmektedir.

Tasarımda öngörülmediği halde elemanın kurulduğu zeminin özelliklerine bağlı olarak ortaya çıkan kaydırak çıkışındaki ters eğim ve sonucundaki su tutma veya giysi yakalanmasına sebebiyet verebilecek açıklıklar gibi uygunsuzluklar montaj sahasında gerekli çalışmalar yürütülerek düzeltilebilecek niteliktedir. Bu noktada, alana bağlı olarak ortaya çıkabilecek uygunsuzlukların nerelerden kaynaklanabileceğinin ortaya konması ve montaj sonrası bu hususların değerlendirilmesi önem taşımaktadır.

Aynı şekilde vida uçları gibi çıkıntı yapan sivri kısımlar da montajın tamamlanmasının ardından standartlara uygun boyutlara getirilmelidir.

Oyun alanı elemanları ile ilgili olarak yürürlükte bulunan standartların muayene ve bakıma ilişkin maddeleri olmasına karşın, üretim yeri ve üretim süreçlerini temel alan ürün belgelendirme faaliyetleri kapsamında bu hususlar değerlendirilememektedir. Ürün belgelendirme faaliyeti çerçevesinde, üçüncü taraf belgelendirme kuruluşu (TSE, oyun alanı elemanları ve zemin düzenlemeleri alanında faaliyet gösteren özel belgelendirme kuruluşları) tarafindan üreticinin/tedarikçinin sunması gereken bilgilerin dokümante edilip edilmediği sorgulanmaktadır. Düzenlenen uygunluk belgeleri incelendiğinde montaj ve bakım ile ilgili maddeleri kapsamadığı görülmektedir. Ancak satış sonrası işletmeye alınan oyun alanında standardın ilgili maddelerinin uygulanıp uygulanmadığı tespit edilememekte ve bu durum belge kapsamlarında belirtilmektedir.

Standarda uygunluğun devamlılı̆̆ , elemanın doğru üretimi ve kurulumu kadar önem arz etmektedir. Bu nedenle, kabul aşamasında oyun alanlarının standartlara uygun olup olmadığının; kabulde uygun olan oyun alanında ise kullanıma açıldıktan sonra herhangi bir olumsuzluğun ortaya çıkıp çıkmadığının tespiti amacıyla gözetim faaliyeti planlanmalı ve yürütülmelidir. Bu sayede, oyun alanlarında yaşanan ve ölümcül sonuçlar doğurabilen kaza ve yaralanmaların önüne geçilmiş olacaktır.

Oyun alanının güvenliğinden sorumlu olan tüm paydaşların standart koşulları konusunda bilinçlenmesi gerekmektedir. Paydaşlar, üreticiler, alım yapan kurumlar, kabul komisyonları ve alanın sürdürülebilirliğinden sorumlu idari yönetimler olarak sıralanabilir. Bu süreçte standartlara uygun tasarımlar yapılması, standartlara uygun olarak tasarlanan ürünlerin aslına uygun üretilmesi ve tasarım ile üretimin birbirine paralel olması amacı ile kalite kontrol faaliyetlerinin gerekliliğinin anlaşılması ve bu faaliyetlerin standartlar konusunda uzmanlaşmış kişiler tarafindan yürütülmesi büyük önem taşımaktadır. Kamusal oyun alanları rekreasyon alanlarının birer parçası olduğundan üretim yerindeki tasarım aşamasından bakıma kadar olan süreçlerde peyzaj mimarları da rol almaktadır. Peyzaj mimarlarının, bu alanda iyi ve doğru işler ortaya koyabilmesi için, sürdürülebilir kalite altyapısı ve standartlar hakkında fikir ve bilgi sahibi olması gerekmektedir. Bunu sağlamak amacıyla, peyzaj alanında lisans ve ön lisans eğitimi veren kurumların kalite ve standardizasyon ile ilgili dersleri müfredatlarına eklemeleri, öğrencilerin kariyer planlamaları açısından yol gösterici olacaktır.

\section{Kaynaklar}

1. Açık, Y., Gülbayrak, C., Turacı Çelik, G. (2004). Investigation of the level of safety and appropriateness of playgrounds in Elazig city in Turkey, International Journal of Environmental Health Research, 75-82.

2. Bae, S., Lee, J. S., Kim, K. H., Park, J., Shin, D. W., Kim, H., Jeon, W. (2017). Playground Equipment Related Injuries in Preschool-Aged Children: Emergency Department-based Injury In-depth Surveillance. Journal of Koren Medical Science. 
3. Cain Ruth, L. (2018). Playground Design and Equipment. Erişim adresi: https://www.wbdg.org/resources/playground-design-and-equipment (erişim: 22.06.2018)

4. Chait, J. (2016). Playground Hazards. Erişim adresi: https://safety.lovetoknow.com/Playground_Hazards (erişim: 02.06.2016)

5. Cronan, K. (2018). Playground Safety. Erişim adresi: https://kidshealth.org/en/parents/playground.html (erişim:22.06.2018)

6. Çolak, F. (2009). Geleneksel Çocuk Oyunları ve Halkbilimsel İncelemesi, Kömen Yayınları, Konya.

7. Dönmez, N. B. (1992). Oyun Kitabı. İstanbul: Esin Yayınevi.

8. Gülay Taş̧̧ı, B. (2010). Sokağın Günümüz Koşullarında Çocuk Oyun Alanı Olarak Ele Alınması ve Değerlendirilmesi, Yüksek Lisans Tezi, Dokuz Eylül Üniversitesi Fen Bilimleri Enstitüsü, İzmir.

9. Jakat, L. (2018). How to Design the Perfect Playground. Erişim adresi: https://www.theguardian.com/lifeandstyle/2012/nov/08/how-to-design-perfect-playground (erişim:22.06.2018)

10. Mecburi Standard Tebliği. Erişim adresi: http://www.resmigazete.gov.tr/eskiler/2017/01/2017012017.htm (erişim: 06.08.2019)

11. Metin, P. (2003). Attributes of Traditional Playground Equipment Design in Children's Developmental Needs, Yüksek Lİsans Tezi, Orta Doğu Teknik Üniversitesi, Endüstri Ürünleri Tasarımı Bölümü, Ankara.

12. Sethi, D., Towner, E., Vincenten, J., Segui-Gomez, M., Raioppi, F. (2008). European Report On Child Injury Prevention, World Health Organization/Europe, Roma.

13. TS EN 1176-1 (2010). Oyun Alanı Elemanları ve Zemin Düzenlemeleri - Bölüm 1:Genel Güvenlik Kuralları ve Deney Yöntemleri, Türk Standardları Enstitüsü, Ankara.

14. TS EN 1176-2 (2010). Oyun alanı elemanları ve zemin düzenlemeleri - Bölüm:2 Salıncaklar için ilave özel güvenlik kuralları ve deney yöntemleri, Türk Standardları Enstitüsü, Ankara.

15. TS EN 1176-3 (2010). Oyun alanı elemanları ve zemin düzenlemeleri - Bölüm:3 Kaydıraklar için ilave özel güvenlik kuralları ve deney yöntemleri, Türk Standardları Enstitüsü, Ankara.

16. TS EN 1176-4 (2010). Oyun alanı elemanları ve zemin düzenlemeleri - Bölüm 4: Kablolu taşıma tesisatları için ilave özel güvenlik kuralları ve deney yöntemleri, Türk Standardları Enstitüsü, Ankara.

17. TS EN 1176-5 (2010). Oyun alanı elemanları ve zemin düzenlemeleri - Bölüm 5: Atlıkarıncalar için ilave özel güvenlik kuralları ve deney yöntemleri, Türk Standardları Enstitüsü, Ankara.

18. TS EN 1176-6 (2010). Oyun alanı elemanları ve zemin düzenlemeleri - Bölüm 6: Sallanma elemanları için ilâve özel güvenlik kuralları ve deney yöntemleri, Türk Standardları Enstitüsü, Ankara.

19. TS EN 16630 (2015). Kalıcı olarak kurulmuş dış mekan egzersiz donanımları - Güvenlik gerekleri ve deney yöntemleri, Türk Standardları Enstitüsü, Ankara.

20. TÜíK Bilgi Edinme (2018). (Çağrı merkezi ile telefon görüşmesi)

21. URL-1 (2015). Public Playground Safety Handbook. Erişim adresi: https://www.cpsc.gov/s3fspublic/325.pdf (erişim: 22.06.2016)

22. URL-2 (2018). Play is the Work of Child. Erişim adresi: https://childdevelopmentinfo.com/childdevelopment/play-work-of-children/\#.W2BE89IzaUk (erişim: 31.07.2018)

23. URL-3 (2018). Erişim adresi: https://www.rospa.com/play-safety/advice/playground-accidents (erişim: 01.08.2018)

24. Uskun, E., Kişioğlu, A. N., Altay, T., Çıkınlar, R., Kocakaya, A. (2008). Assessment of The Current Status Of Playground Safety in the Midwestern Region of Turkey: An Effort To Provide A Safe Environment For Children, The Turkish Journal of Pediatrics, 559-565.

25. Yılmaz, B. M. (2018). Oyun alanı elemanları ve zemin düzenlemeleri kapsamında yapılan muayene ve deneyler hakkında telefon görüşmesi (H. M. Sarıaslan Senyen, Röportaj Yapan)

26. Yılmaz, S., Bulut, Z. (2002). Kentsel Mekanlarda Çocuk Oyun Alanları Planlama ve Tasarım İlkeleri. Atatürk Üniversitesi Ziraat Fakültesi Dergisi, 345-351.

27. Yörükoğlu, A. (2004). Çocuk Ruh Sağlığı, Özgür Yayınları, İstanbul. 